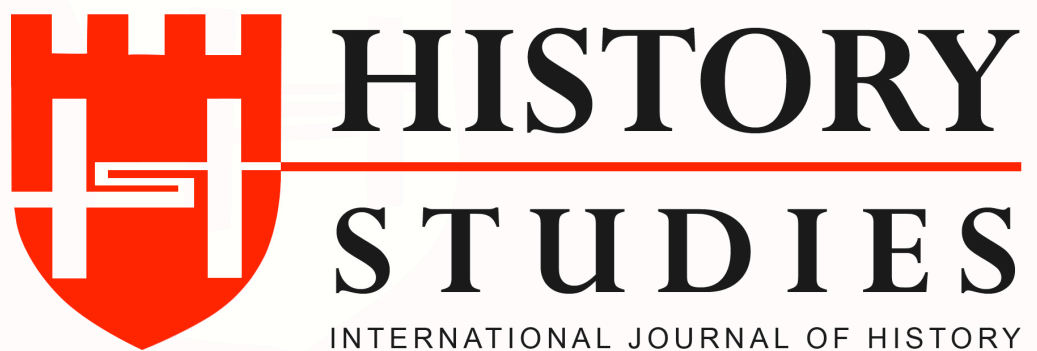

ISSN: 13094173 (Online) 1309 - 4688 (Print)

Volume 11 Issue 5, October 2019

DOI Number: 10.9737/hist.2019.790

Araştırma Makalesi

Makalenin Geliş Tarihi: 09.07.2019 Kabul Tarihi: 03.10.2019

Atıf Künyesi: Murat Zengin, "Memlûklu Devlet Adamı Emir Çekem ve İsyanları”, History Studies, 11/5, Ekim 2019, s. 1855-1873.

\title{
Memlûklu Devlet Adamı Emir Çekem ve İsyanları
}

\author{
Mamluks Statesman Amir Çekem and His Rebellions
}

\author{
Dr. Murat Zengin \\ ORCID No: 0000-0002-8528-7308 \\ İn̈̈ӥ̈ Üniversitesi
}

\begin{abstract}
Öz: Bahrî Memlûkleri döneminin ilk sultanı Berkûk'un memlûklerinden olan Emir Çekem, Ferec döneminde Kahire ve Dımaşk emirleri arasındaki rekabetten istifade ederek nüfuz kazanmıştır. Devletin ikinci merkezi durumunda olan Bilâd-1 Şam'ın (Suriye) Timur tarafından işgal edilmesiyle bölgede ciddi sorunlar ortaya çıkmıştır. Timurlu kuvvetlerinin bölgeden çekilmesinden sonra bölge yeniden Memlûklu hâkimiyetine girdiyse de burada görev yapan Memlûklü devlet adamlarından bazıları, Sultan Ferec'in tecrübesizliğinden de istifade ederek merkez Kahire'ye karşı isyan etmişlerdir. Bu devlet adamlarından biri olan Emir Çekem, üç kez isyan etmiştir. Halep niyâbeti görevini yürüttüŭg̈ sırada çıkardığı ilk isyanında Kahire'yi kuşattıysa da başarısız olarak çekilmek zorunda kalmıştır. İkinci isyanı Sultan Ferec tarafından bastırılmıştır. Çekem'in üçüncü isyanı, Memlûklu tarihinde görülen diğer isyanlardan farklı olarak bir istiklâl mücadelesine dönüşmüştür. Devlet tahtını elde etmek yerine Halep merkezli yeni bir siyasî teşekkül oluşturma düşüncesiyle harekete geçen Çekem, kısa süreliğine de olsa Gazze'den Elbistan'a kadar olan geniş sahada istiklâlini ilân etmiştir. Melikü'l-Âdil Ebû'l-Fütûh Seyfeddin Çekem adıyla kendisini sultan ilân etmiş, kurduğu bu yeni teşekkülün sınırlarını genişletmek amacıyla Diyarbakır'ı ele geçirmeye çalıșmıs ve burada Akkoyunlu Beyi Kara Yülük Osman ile giriștiği mücadelede hayatını kaybetmiştir. Makalemizde, Emir Çekem'in hayatı ve isyanları hakkında ayrıntılı bilgi verilecektir.
\end{abstract}

Anahtar Kelimeler: Ferec, Bilâd-1 Şam, Çekem, İsyan

Abstract: Amir Çekem, one of Berkûk's first sultans of the Bahrî Mamluks, gained influence by taking advantage of the rivalry between the orders of Cairo and Damascus during the reign of Faraj. With the occupation of Bilād-i Şām (Syria), the second center of the state, by Timur, serious problems arose in the region. After the withdrawal of the Timurid forces from the region, the region came under the rule of Mamluks again, but some of the Mamluks statesmen rebelled against central Cairo, benefiting from the inexperience of Sultan Faraj. Amir Çekem, one of these statesmen, rebelled three times. Although Aleppo besieged Cairo in its first rebellion during its mission, it had to withdraw. The second rebellion was suppressed by Sultan Faraj. Çekem's third rebellion turned into a struggle for independence, unlike the other rebellions seen in Mamluks history. Acting with the idea of creating a new political organization based in Aleppo instead of obtaining the state throne, Cekem declared his independence in a wide area from Gaza to Elbistan for a short time. Declared himself a sultan by the name of al- Malīk al- Ādil Abū'l-Fütūh Sayf al-din Çekem, tried to seize Diyarbakır in order to expand the boundaries of this new organization he founded and lost his life here in the struggle with Kara Yülük Osman, the ruler of Aqqoyunlu. In this article, detailed information about Amir Çekem's life and rebellions will be given.

Keywords: Faraj, Bilād-1 Şām, Çekem, Revolt 


\section{Giriş}

Memlûk Türk Devleti, kısa bir dönem hariç monarşiye dayalı bir yönetim anlayışıyla idare edilmiştir. Memlûk sistemi içerisinde yetişen bir asker, hiyerarşik yükselişinin ardından şartlar lehine olduğu ve gerekli desteği sağladığı sürece saltanat makamını elde edebiliyordu. Sistemin doğasından kaynaklanan bu özellikten dolayı Memlûklu Devleti’nde bir hanedan oluşamadığ gibi taht kavgalarına da sıklıkla tesadüf edilmiştir. Sultan Melikü'n-Nâsır Muhammed b. Kalavûn (1293-1294/1299-1309/1310-1341), emirlerin tahakkümünü kırmak noktasında ciddi tedbirler alarak bir merkezi otorite kurmayı başarsa da vefatının ardından devlet, yeniden emirlerin kontrolüne geçmiştir. ${ }^{1}$ Sultan ile emirler arasındaki bu otorite rekabeti, siyasî, askerî ve sosyo-ekonomik boyutlarıyla önemli sorunlara yol açmıştır.

Memlûklu tarihinde birçok önemli isyan yaşanmıştır. Yelboğa el-Yahyâvî, ${ }^{2}$ Bayboğa Arus $^{3}$ ve Mintaş ${ }^{4}$ İsyanları bunlardan bazılarıdır. Emir Çekem İsyanı, mahiyeti bakımından diğer isyanlarla benzerlik gösterse de amacı ve sonucu bakımından Memlûklu tarihinde istisnaî bir yere sahiptir. Halep nâibi Emir Çekem tarafından başlatılan bu isyan onun istiklâlini ilânıyla neticelenmiş; Çekem'in Akkoyunlu topraklarına saldırmasıyla da uluslararası bir boyut kazanmıştır.

Bahrî Memlûkleri döneminin ilk sultanı olan Melikü'z-Zahîr Berkûk'un (1382-1389/13901399) memlûklerinden olan Çekem, Berkûk'un yetiştirmesi sıfatıyla onun ölümünden sonra yerine geçen oğlu Ferec'in (1399-1405/1405-1412) saltanatının başlarında adından söz ettirdi. Sultan Ferec'in yaşı küçük olduğu gerekçesiyle idareye müdahale eden bazı emirlere karşı Emir Tenem ve Emir Aytemuş tarafından başlatılan isyanın bastırılmasında ilk başarısını gösterdi. $\mathrm{Bu}$ başarısından aldığı cesaretle Sultan Ferec üzerinde tahakküm kurmaya çalıştıysa da İskenderîye Hapishanesi'nde tevkif edilmekten kurtulamadı.

\section{1- Emir Çekem Hakkındaki İlk Bilgiler}

Memlûklu devlet adamı Emir Çekem'in ne zaman, nerede doğduğu ve Memlûklu Devleti'nin hizmetine ne zaman girdiği hususu belirsizdir. Kaynaklar ittifak ile onun Avaz adlı bir tüccâr veya emir tarafından Memlûk ülkesine getirildiği belirtmektedirler. ${ }^{5}$ Çekem'den ilk kez Makrizî, İbn Hacer, İbn Tağrıberdi, Sayrafî, İbn Îyâs ve Sehâvî, Sultan Berkûk'un son, Sultan Ferec'in saltanatının ilk dönemleri hakkında bilgi verirken bahsetmektedirler. $\mathrm{Bu}$ müelliflerden Makrizî, 30 Aralık 1398'de imret-i aşere makamında bulunduğunu kaydetmek suretiyle Çekem hakkındaki ilk bilgileri vermektedir. ${ }^{6}$ İbn Hacer, Ağustos-Eylül 1399'da gerçekleşen Şeyh Takıyüddin Ahmed'in (meşhur tarihçi Makrizî) Kahire Hisbeliği makamına atanması hadisesine bazı emirlerin itiraz ettiğini ve itiraz eden bu emirlerden birinin Çekem olduğunu kaydetmekle birlikte hadise sırasında Çekem'in hangi rütbede olduğunu

\footnotetext{
${ }^{1}$ Murat Zengin, "Melikü’n-Mansûr Ebî Bekr b. Muhammed Dönemi Memlûk Türk Devleti Tarihi (Elli Dokuz Günlük Saltanat)", History Studies, C. X, 3, April 2108, s. 259.

${ }^{2}$ Yelboğa el-Yahyâvî İsyanı hakkında ayrıntılı bilgi için bkz. Murat Zengin, "Melikü'l-Muzaffer Zeyneddin Haccî Döneminde Memlükler", Tarihin Peşinde- Uluslararası Tarih ve Sosyal Araştırmalar Dergisi, C. X/, 20, Ekim 2018, s. 366-367.

3 Bayboğa Arus İsyanı hakkında ayrıntılı bilgi için bkz. Murat Zengin, "Sultan Selâhaddin Sâlih Döneminde Memlükler", Tarih Okulu Dergisi, C. XII, 39, Nisan 2019, s. 319-322.

${ }^{4}$ Mintaş İsyanı hakkında ayrıntılı bilgi için bkz. Murat Zengin, İlhanlılar-Eratnalılar-Memlûkler Dönemi Malatya (1295-1401), Malatya Kitaplığı, İstanbul 2017, s. 105-112.

${ }^{5}$ Makrizî, es-Sülûk li-Marifet-i Düvelü'l-Mülûk, Tahkik: Muhammed Abdülkadir Âtâ, C. 5, Beyrut 1997, s. 433; İbn Tağrıberdî, en-Nücûmu'z-Zâhire fî Mülûk-ı Mısr ve'l-Kâhire, Tahkik: Muhammed Hüseyin Şemseddin, C. 12, Beyrut 1992, s. 140.

${ }^{6}$ Makrizî, a.g.e., C. 5, s. 433.
} 
belirtmemiştir. ${ }^{7}$ İbn Tağrıberdî, en-Nücûmu'z-Zâhire adlı eserinde Temmuz-Ağustos 1399 itibarıyla Çekem'in imret-i aşere makamında olduğunu kaydederek Makrizî’yi teyit etmekte ${ }^{8}$; ayrıca 9 Temmuz 1399 'da Çekem'in reis-i nevbet makamına atandığını da belirtmektedir. ${ }^{9}$ Fakat aynı müellif diğer eseri Menhelü's-Sâfı' de 30 Aralık 1398 itibarılyla Çekem'in kırklar emirliği (imret-i tablhane) makamına atandığını kaydetmektedir. ${ }^{10}$ Sayrafî, Çekem'in 13 Temmuz 1399 tarihinde reis-i nevbet-i siğâr; ${ }^{11}$ İbn Îyâs ve Sehâvî ise ay belirtmeden 1399 y1lı içerisinde Çekem'in Berkûk tarafından kırklar emirliği makamına atandığını kaydetmektedirler. ${ }^{12} \mathrm{Bu}$ bilgiler 1şığında Çekem'in Berkûk tarafından azat edildikten sonra imret-i aşere ve imret-i tablhane rütbelerine atandığını; tablhane rütbesinde bir asker olduğu için reis-i nevbet makamına getirildiğini söyleyebiliriz.

Memlûk, bir tüccar tarafından belirli bir bedel karşı1lığı alınıp satılan veya savaşlarda esir edilmek suretiyle hürriyeti tahdid edilen, hukuki bir statüsü olan, başta askerlik yeteneği olmak üzere çeşitli yeteneklere sahip olup belli bir eğitim aşamasından başarı ile geçtikten sonra efendisi veya üstazı tarafından azat edilerek askeri ve idari görevlere getirilen askerin adıdır. Memlûk Türk Devleti'nde sisteme dâhil edilen bir memlûk, tibak adı verilen kışlalarda teorik ve pratik eğitimden geçtikten sonra mezun olurdu. Mezun olan bir memlûk, sırasıyla imret-i aşere (onbaşı), imret-i işrîn (yirmibaşı), imret-i tablhane (kırk-seksenbaşı), imret-i mie (yüzbaşı) ve takdimetü'l-elf (binbaşı) rütbelerine atanırdı. Emir Çekem hakkındaki ilk bilgiler, onun imret-i aşere rütbesine atanmasıyla ilgili olsa da Çekem'in bu atamadan önceki bir tarihte sisteme dâhil edildiği söylenebilir. Ayrıca İbn Hacer ve Sehâvî, onun Berkûk'un memlûklerinden birisi olduğunu belirterek künyesini "Çekem b. Abdillah Ebû'l-Fereç ezZâhirî" şeklinde ${ }^{13}$, İbn Tağrıberdî ise künyesini "Çekem b. Abdullah min Avaz ez-Zâhirî Emir Seyfeddin olarak kaydetmektedirler. ${ }^{14}$ İbn Tağrıberdî, Çekem'in Sultan Berkûk'un azatlısı olduğunu açıkça belirtmektedir. ${ }^{15}$ Emir Çekem' in tam künyesi ise "Melikü's-Seyfeddin Çekem b. Abdillah Ebû'l-Ferec ez-Zâhirî"dir. ${ }^{16}$

\section{2- Mısır'daki Faaliyetleri}

Sultan Ferec'in iktidarının ilk dönemlerinde Dımaşk nâibi emir Tenem, Humus ve Hama'yı ele geçirerek isyan etmişti. ${ }^{17}$ Atabekü'l-asakir makamında bulunan Emir Aytemüş, Tenem'e destek olmak üzere Dımaşk'a gidince Sultan Ferec bir dizi tedbir alarak birçok emire bağışlarda bulundu. Aralık 1399'da reis-i nevbet-i siğâr rütbesindeki Çekem'e de bağışta bulunan ${ }^{18}$ Sultan Ferec, kısa süre sonra o sırada Gazze'ye kadar ulaşmış olan Tenem-Aytemüş önderliğindeki muhalifleri dağıtmak üzere 7.000 kişilik bir kuvvetle Gazze'ye gitti. Muhalif

\footnotetext{
7 İbn Hacer, İnbâu'l-Ğumr Ebnâi'l-Umr, Tahkik: Hasan Habeşî, C. 2, Kahire 2011, s. 54.

${ }^{8}$ İbn Tağriberdî, a.g.e., C. 12, s. 140.

9 A.g.e., C. 12 , s. 165.

${ }^{10}$ İbn Tağriberdî, el-Menhelü's-Sâfì ve'l-Müstevfî bâde'l-Vâfî, Tahkik: Muhammed Muhammed Emin, C. 4, Kahire 1986, s. 313.

${ }^{11}$ Sayrafî, Nüzhetü'n-Nüfûs ve'l-Abidân fì Tevârihi'z-Zamân, Tahkik: Hasan Habeşî, C.2, yy. 1971, s. 17.

12 İbn Îyâs, Bedâiü'z-Zuhûr fî̀ Vekâiü'd-Duhûr, yy., 1960, s. 269; Sehâvî, ed-Dâvü'l-Lâmî li-Ehli'l-Karni't-Tâsî, C.

3, Beyrut 1992, s. 76.

13 İbn Hacer, a.g.e., C. 2, s. 364; Sehâvî, a.g.e., C. 3, s. 76.

${ }_{14}$ İbn Tağriberdî, el-Menhelü's-Sâfí, C. 4, s. 313.

15 A.g.e., C. 4, s. 313.

16 İbn Hacer, a.g.e., C. 2, s. 364; İbn Tağrıberdî, el-Menhelü's-Sâfî, C. 4, s. 313; Sehâvî, a.g.e., C. 3, s. 76; Sayrafî, a.g.e., C. 2, s. 232.

${ }^{17}$ Makrizî, a.g.e., C. 6, s. 23-25; İbn Hacer, a.g.e., C. 2, s. 91-97; İbn Tağrıberdî, en-Nücûmu'z-Zâhire, C. 12, s. 156159; Esra Çıplak, el-Melik en-Nâsır Ferec b. Berkuk Devri Memlûk Sultanlı̆̆ı (791-815/1389-1412), Basılmamış Yüksek Lisans Tezi, Gazi Üniversitesi Sosyal Bilimler Enstitüsü, Ankara 2005, s. 23; Asri Çubukçu, "Ferec", DİA, C. 12, İstanbul 1995, s. 370-371.

${ }^{18}$ İbn Tağriberdî, en-Nücûmu'z-Zâhire, C. 12, s. 155.
}

\section{History Studies}


emirlerle Gazze'de yapılan savaşı Ferec kazandı ve Tenem esir edilirken Emir Aytemüş ve diğer muhalifler Dımaşk'a kaçmayı başardılar. ${ }^{19}$ Sultan Ferec, Emir Çekem'i Dımaşk'a kaçan âsileri yakalamak üzere görevlendirdi. ${ }^{20} \mathrm{Bu}$ sırada Sultan ile birlikte Gazze'de olduğu anlaşılan Çekem, Mart-Nisan 1400'de Dımaşk'a yöneldi ve Aytemüş ve diğer âsi emirleri yakalamayı başararak Dımaşk Kalesi'nde hapsetti. ${ }^{21}$ Bu gelişmeden kısa süre sonra Sultan Ferec Dımaşk'a girip Tenem ve Aytemüş başta olmak üzere diğer âsi emirleri öldürdü. Sultan, 21 Mayıs 1400 'de Kahire'ye döndükten iki gün sonra 23 Mayıs'ta içerisinde Çekem'in de bulunduğu birçok emiri Tenem isyanını bastırmadaki başarılarından dolayı üst rütbelere atadı. Çekem, Hama niyabetine atanan Emir Dokmak el-Muhammedî yerine takdimetü'l-elf rütbesine yükseltildi. ${ }^{22}$

Tenem isyanının bastırılmasından kısa süre sonra Memlûk Devleti büyük bir tehditle karşı karşıya kaldı. Timur, 1400 yılı sonlarında yeniden Anadolu seferine çıkmış, Erzincan, Sivas, Elbistan ve Malatya'yı ele geçirdikten sonra Halep'e hareket etmişti. ${ }^{23}$ Sultan Ferec, Timur ile karşılaşmak üzere Dımaşk seferine çıkmaya karar verdi. Sefere çıkmadan önce Kahire'de bir takım düzenlemeler yapan sultan, Emir Tımraz en-Nâsırî̀yi niyâbet-i gaybe makamına atadı. İçerisinde Emir Çekem'in de bulunduğu bazı emirleri ise sefer ihtiyaçlarını tedarik etmekle görevlendirdi. Çekem ve diğer emirler, 1.000 at ve deveyi tedarik ederek o sırada Dımaşk seferi için Reydaniye'de bulunan sultana teslim ettiler. ${ }^{24}$ Ferec, Ocak 1401 'de Dımaşk seferine çiktı. Halep ve mülhakatının Timur tarafından ele geçirilmesi üzerine Dımaşk'ta bulunan sultan, Kahire'den takviye kuvvetler talep etti. Kahire'de niyâbet-i gaybe makamında bulunan Emir Tımraz, sultanın destek kuvvet talebi üzerine Emir Akbay, Emir Cerbâş eş-Şeyhî, Emir Tümentimur, Emir Sumay el-Hasenî ve Emir Çekem'i Dımaşk'a yollamak istediyse de Emir Çekem, Dımaşk'a gitmeyi kabul etmedi ve diğer emirlerin gidişini de engelledi. ${ }^{25}$ Halep'i ele geçirdikten sonra Dımaşk önlerine gelen Timur, Sultan Ferec'e sulh teklifinde bulundu; fakat Ferec onun bu teklifini kabul etmedi. Timur ile savaşmaktan çekinen Memlûklu emirlerinden Sûdûn Tayyâr, Kanıbay el-Âlâî, Cumuk ve Yeşbek el-Osmanî, sultanın savaş ısrarı üzerine Dımaşk önlerinden ayrılarak Şeyh Lâçin el-Çerkesî̀yi sultan ilan etmek üzere Kahire’ye hareket ettiler. ${ }^{26} \mathrm{Bu}$ gelişme üzerine Ferec, tahtını kurtarmak amacıyla Dımaşk’tan ayrılarak süratle Kahire'ye döndü. ${ }^{27}$ Ferec'in ayrılmasından sonra Dımaşk, Timur tarafından ele geçirildi.

Sultan Ferec, Kahire'ye döndükten sonra yeni bir sultan ilan etmek üzere Dımaşk'ta kendisinden ayrılanlar ile Kahire'den Dımaşk'a gitmeyi kabul etmeyen emirleri cezalandırmak istedi. Emir Cekem önderliğinde Sûdûn Tayyâr, Kanıbay el-Âlâî, Korkmaz el-İnal, Cumuk, Timurboğa el-Meştûb ve diğer emirlerden oluşan muhalifler sultanla savaşmak üzere Birketi'lCeyş/Ordu Gölü bölgesinde toplandılar. ${ }^{28}$ Sultan Ferec, Emir Çekem'i ittifaktan koparmak amacıyla ona Hama niyâbeti makamını teklif etti. ${ }^{29}$ Çekem ise sultana "Biz, sultanın

\footnotetext{
19 İbn Hacer, a.g.e., C. 2, s. 101; İbn Tağriberdî, en-Nücûmu'z-Zâhire, C. 12, s. 165.

${ }^{20}$ İbn Hacer, a.g.e., C. 2, s. 364; İbn Tağrıberdî, en-Nücûmu'z-Zâhire, C. 12, s. 167; Sayrafî, a.g.e., C. 2, s. 54.

${ }^{21}$ Makrizî, a.g.e., C. 6, s. 25-26; İbn Hacer, a.g.e., C. 2, s. 101; İbn Tağriberdî, en-Nücûmu'z-Zâhire, C. 12, s. 168; Sayrafî, a.g.e., C. 2, s. 54; İbn Îyâs, a.g.e., s. $280 \mathrm{vd.}$

${ }_{22}$ Makrizî, a.g.e., C. 6, s. 29; İbn Hacer, a.g.e., C. 2, s. 364; İbn Tağrıberdî, en-Nücûmu'z-Zâhire, C. 12, s. 171; Sayrafî, a.g.e., C. 2, s. 58; İbn Îyâs, a.g.e., s. 282.

${ }_{23}$ İbn Hacer, a.g.e., C. 2, s. 133-134; İbn Tağriberdî, en-Nücûmu'z-Zâhire, C. 12, s. 175-177; Sayrafî, a.g.e., C. 2, s. 72, 74; İbn Îyâs, a.g.e., s. 283 vd.

${ }^{24}$ Makrizî, a.g.e., C. 6, s. 44; İbn Tağrıberdî, en-Nücûmu'z-Zâhire, C. 12, s. 184.

${ }^{25}$ Makrizî, a.g.e., C. 6, s. 58.

${ }^{26}$ İbn Tağriberdî, en-Nücûmu'z-Zâhire, C. 12, s. 188-189; İbn Îyâs, a.g.e., s. 287.

27 İbn Tağriberdî, en-Nücûmu'z-Zâhire, C. 12, s. 189; Sayrafî, a.g.e., C. 2, s. 87; İbn Îyâs, a.g.e., s. 287.

${ }^{28}$ Makrizî, a.g.e., C. 6, s. 61-62; İbn Hacer, a.g.e., C. 2, s. 145; İ̉n Tağrıberdî, en-Nücûmu'z-Zâhire, C. 12, s. 212-

213; a. mlf., el-Menhelü's-Sâfí, C. 4, s. 314; Sayrafî, a.g.e., C. 2, s. 110.

${ }^{29}$ Makrizî, a.g.e., C. 6, s. 62; İbn Tağrıberdî, en-Nücûmu'z-Zâhire, C. 12, s. 214; Sayrafî, a.g.e., C. 2, s. 109.
}

\section{History Studies}


memâlikiyiz. Sultan ve babası (Berkûk) bizim üstazımızdır. Eğer sultan bizi öldürmek istiyorsa bundan sakınmasın. Bizim bizden başka dostumuz da düşmanımız da yoktur" şeklinde bir cevap yolladı. ${ }^{30}$ Ferec, Çekem'in bu cevabı üzerine Emir Nevrûz el-Hafızî ve Şâfî kadısı Nasıreddin'den oluşan bir heyeti barış talebiyle Çekem'e yolladı. ${ }^{31}$ Nevrûz; Çekem ve müttefiklerini sultan ile görüşmek üzere ikna etti. Muhalifler adına Çekem ve Sûdûn Tayyâr, sultanla görüşmek üzere huzura çıkınca devadâr-1 kebir Yeşbek el-Şâbânî "Çekem ve yanındakileri yakalayana 1000 dirhem!" diye bağırdı ve bir arbede yaşandı. Bu arbede sonucunda devadâr-1 kebir Yeşbek ve Emir Kutluboğa yakalanıp İskenderiye Hapishânesine yollandılar. ${ }^{32}$ Emir Çekem, Yeşbek yerine 2 Haziran 1401'de devadâr-1 kebirlik makamına atand1. ${ }^{33}$ Çekem, Berkûk'un memlûklerinden birisi olduğu için etki sahibi idi. Bu yeni göreve atanmasıyla devlet içerisindeki nüfuzunu arttırdı. Nitekim müellif İbn Tağrıberdî, Çekem'in ülke işleri üzerindeki tahakkümünün Haziran 1401 'de başladığını kaydederek bu hususa vurgu yapmaktadır. ${ }^{34}$

Timur'un Halep'e inmesi üzerine onunla mücadeleye memur edilen Dımaşk nâibi Seyyidî Sûdûn, Timur'a esir düşmüştü. Sultan Ferec, Timur ile karşılaşmak üzere Dımaşk'a hareket edip Gazze'ye ulaşınca esir düşen Sûdûn yerine Dımaşk niyâbetine Emir Tağrıberdî'yi atamışt. ${ }^{35}$ Timur'un Karabağ'a dönüşünün ardından Dımaşk ve Halep yeniden Memlûklu hâkimiyetine girdi. Halep nâibi Emir Demirtaş, Dulkadirli Halil Bey ve emrindeki Türkmenlerle ittifak ederek isyan etmişti. Dımaşk nâibi Tağrıberdi, sultana itaatsizliği nedeniyle görevinden alınmak istenince isyan halindeki Halep nâibine sığındı. Bu gelişmeler üzerine sultan, Ağustos-Eylül 1401'de Emir Tağrıberdî'yi Dımaşk niyabetinden azlederek yerine Emir Akboğa el-Cemâlî el-Etruş'u, âsi Halep nâibi Demirtaş yerine ise Safed nâibi Emir Dokmak el-Muhammedî'yi atad. ${ }^{36}$

Misır emirlerinden olan Sûdûn Taz, Emir Çekem başta olmak üzere Emir Nevrûz, Timurboğa el-Meştûb ve Kanıbay gibi emirlerin sultan ve devlet üzerindeki tahakkümünden rahatsız olduğu için bu emirleri ortadan kaldırmak üzere harekete geçti. Sultan Ferec, Halep ve çevresindeki karışıklıkların devam ettiği bir dönemde Kahire'de ortaya çıkan bu sorunu çözmek adına Sûdûn Taz el-Hamzavî'yi savaştan vazgeçirerek onu Halep'e atanan Dokmak elMuhammedî yerine 6 Ekim 1401'de Safed nâibi olarak atadı. Hamzavî ile savaşmak üzere olan Emir Çekem ve Emir Nevrûz görevlerinden alınarak bir müddet sultanın huzuruna girmekten alıkonuldular. ${ }^{37}$ Emir Çekem, devadâr-1 kebir; Emir Nevrûz ise devadâr-1 sâni idi. Çekem yerine Emir Tanbek, Nevrûz yerine Emir Cumuk getirildi. ${ }^{38}$ Fakat Emir Demirtaş, Emir Tağrıberdî ve Dulkadirli Halil Bey'in önderliğindeki Halep isyanı büyüdüğünden sultan durumun nezaketine binaen önce Nevrûz'u ardından da Çekem'i yeniden görevlerine iade etti. ${ }^{39}$ Ayrıca Dımaşk nâibi Akboğa el-Etruş ile Halep'e atanan Emir Dokmak el-Muhammedî’yi Halep isyanını bastırmakla görevlendirdi. ${ }^{40}$ Emir Çekem görevine iade edildikten bir süre sonra Emir Sûdûn Taz ile yeniden bir anlaşmazlık yaşadı. Sûdûn Taz'ın sultan üzerindeki tahakkümünden rahatsız olan Çekem ve Nevrûz bu hususu açığa vurduklarından Sultan Ferec

\footnotetext{
${ }^{30}$ Makrizî, a.g.e., C. 6, s. 62; İbn Tağrıberdî, en-Nücûmu'z-Zâhire, C. 12, s. 214.

${ }^{31}$ İbn Tağrıberdî, en-Nücûmu'z-Zâhire, C. 12, s. 214; Sayrafî, a.g.e., C. 2, s. 110.

${ }^{32}$ Makrizî, a.g.e., C. 6, s. 62-63; İbn Tağriberdî, en-Nücûmu'z-Zâhire, C. 12, s. 214; Sayrafî, a.g.e., C. 2, s. 112 vd.

${ }^{33}$ Makrizî, a.g.e., C. 6, s. 63; İbn Tağriberdî, en-Nücûmu'z-Zâhire, C. 12, s. 216; Sayrafî, a.g.e., C. 2, s. 113.

${ }_{34}$ İbn Tağriberdî, en-Nücûmu'z-Zâhire, C. 12, s. 217.

35 İbn Tağriberdî, en-Nücûmu'z-Zâhire, C. 12, s. 184.

${ }^{36}$ İbn Hacer, a.g.e., C. 2, s. 199-200; İbn Tağrıberdî, en-Nücûmu'z-Zâhire, C. 12, s. 219; Sayrafî, a.g.e., C. 2, s. 135.

${ }^{37}$ İbn Hacer, a.g.e., C. 2, s. 201; İbn Tağrıberdî, en-Nücûmu'z-Zâhire, C. 12, s. 220; Sayrafî, a.g.e., C. 2, s. $136,137$.

${ }^{38}$ Makrizî, a.g.e., C. 6, s. 74.

${ }^{39}$ Makrizî, a.g.e., C. 6, s. 73; İbn Tağriberdî, en-Nücûmu'z-Zâhire, C. 12, s. 220.

${ }^{40}$ İbn Tağriberdî, en-Nücûmu'z-Zâhire, C. 12, s. 220.
}

\section{History Studies}


tarafından huzurdan men cezasına çarptırıldılar. Ocak-Şubat 1402'de başlayan bu tecrid süreci Nisan-Mayıs 1402'ye kadar devam etti. Öyle ki bu iki emirin sultana olası bir suikastına karşı sultan ile birlikte bayram namazını kılmaları bile engellendi. ${ }^{41}$ Çekem ve Nevrûz, Emir Sûdûn Taz'1 ortadan kaldırmak için Mayıs-Haziran 1402'de harekete geçince Sultan Ferec, Halife Mütevekkil Alelallah ve dört içtihat kadısını Nevrûz ve Çekem'e yollayarak onları vazgeçirmek istediyse de bu iki emir barışa razı olmadılar. ${ }^{42}$ Sultan, bu iki emirle yeniden anlaşma yoluna gitti ve neticede Nevrûz ve Çekem huzura çıkmayı kabul ettiler. ${ }^{43}$

Nevrûz ve Çekem huzura kabul edildikten sonra Emir Sûdûn Taz'ı ortadan kaldırmak üzere yeniden harekete geçtiler. Kurdukları ittifaka reis-i nevbet Emir Çeribaş eş-Şeyhî, ikinci hâcip Emir Beşbay, hazinedâr Emir Kamış el-Hasekî, Emir Yeşbek el-Hasekî, Emir Yeşbek elOsmanî, Emir Altunboğa el-Camus, Cânıbek et-Tayyibî, Barsboğa ed-Devadâr ve Turbay edDevadâr da katıldılar. Birketi'l-Ceyş'de toplanan muhalif emirlere, Emir Kanıbay, Emir Korkmaz, Emir Argun, Sûdûn Zâde ve Timurbuğa el-Meştûb'un liderliğindeki memâlik-i sultandan 1.500 memlûk katıldı. Sultan Ferec, Birketi'l-Ceyş'de konuşlanmış olan ÇekemNevrûz önderliğindeki bu kalabalık kuvvetler üzerine büyük bir saldırı gerçekleştirildi. ${ }^{44}$ Saldırı neticesinde Timurboğa el-Meştûb, Sûdûn Zâde gibi emirler esir edilerek İskenderiye Hapishanesi'ne gönderildiler. Çekem ve Nevrûz ise kaçmayı başardılar. ${ }^{45}$

Çekem ve Nevrûz, önce Minyeti'l-Kâid'de (Kaid Köyü) ardından Ceyize'ye bağlı Bulak Adası yakınlarındaki Tamveh Köyü'de gizlenmişlerdi. Emir Nevrûz burada Çekem'den ayrılarak gece karanlığından da istifade ile Kahire’ye gitti ve Emir-i Kebir Baybars'ın evine sığındı. Emir Demirtaş, Emir Tağrıberdî ve Dulkadirli Halil Bey tarafından başlatılmış olan isyanı bastırmak üzere görevlendirilen Emir Dokmak el-Muhammedî’nin başarısız olması üzerine Sultan Ferec, Emir Nevrûz'u affetti. ${ }^{46}$ Emir Çekem, Nevrûz'un Kahire'ye gidişinden kısa süre sonra yakalandı ve 25 Mayıs 1402 'de İskenderiye Hapishanesi'ne yolland ${ }^{47}$ Çekem'in hapsedilmesiyle boşalan devadârlık makamına İskenderiye Hapishanesi'nden çıarılan sâbık devadâr Emir Yeşbek el-Şabanî atandı. ${ }^{48}$

\section{3- İskenderiye Günleri}

Emir Çekem, Emir Nevrûz ile birlikte Sûdûn Taz'a karşı giriştiği mücadeleyi kaybettikten sonra yakalanarak 25 Mayıs 1402'de İskenderiye Hapishanesi'ne yollanmıştı. 26 Mayıs'ta ise İskenderiye Hapishanesi'ne konuldu. ${ }^{49}$ Çekem'in bertaraf edilmesinden hemen sonra onun yerine devadârlık makamına yeniden atanan Emir Yeşbek el-Şabanî, kısa süre içerisinde devletin kontrolünü ele geçirerek sultan üzerinde yeniden bir tahakküm kurdu. Otoritesi için tehdit oluşturan nüfuzlu emirleri tasfiye etmek isteyen Yeşbek, Emir Nevrûz'u, Emir Kanıbay’1

\footnotetext{
${ }^{41}$ İbn Tağriberdî, en-Nücûmu'z-Zâhire, C. 12, s. 221; Sayrafî, a.g.e., C. 2, s. 139.

42 İbn Tağriberdî, en-Nücûmu'z-Zâhire, C. 12, s. 221.

43 İbn Hacer, a.g.e., C. 2, s. 202 vd; İbn Tağrıberdî, en-Nücûmu'z-Zâhire, C. 12, s. 222; Sayrafî, a.g.e., C. 2, s. 139; İbn Îyâs, a.g.e., s. 299.

${ }^{44}$ Makrizî, a.g.e., C. 6, s. 76-77; İbn Tağrıberdî, en-Nücûmu'z-Zâhire, C. 12, s. 222; a. mlf., el-Menhelü's-Sâfî, C. 4, s. 315; Sayrafî, a.g.e., C. 2, s. 140 vd; İbn Îyâs, a.g.e., s. 300.

${ }^{45}$ Makrizî, a.g.e., C. 6, s. 77; İbn Hacer, a.g.e., C. 2, s. 203; İbn Tağrıberdî, en-Nücûmu'z-Zâhire, C. 12, s. 223; Sayrafî, a.g.e., C. 2, s. 141; İbn Îyâs, a.g.e., s. 301.

46 İbn Tağriberdî, en-Nücûmu'z-Zâhire, C. 12, s. 223; Sayrafî, a.g.e., C. 2, s. 142.

${ }^{47}$ İbn Hacer, a.g.e., C. 2, s. 203; İbn Tağrıberdî, en-Nücûmu'z-Zâhire, C. 12, s. 223-224; Sayrafî, a.g.e, C. 2, s. 143; İbn Îyâs, a.g.e., s. 301.

${ }^{48}$ Makrizî, a.g.e., C. 6, s. 78; İbn Tağriberdî, en-Nücûmu'z-Zâhire, C. 12, s. 224; a. mlf., el-Menhelü's-Sâfí, C. 4, s.

316; Sayrafî, a.g.e., C. 2, s. 145; İbn Îyâs, a.g.e., s. 301.

49 İbn Tağriberdî, en-Nücûmu'z-Zâhire, C. 12, s. 224.
} 
ve emekliliğe sevk edilerek Serhat'te ikamete mecbur edilen Emir Sûdûn Taz'1 Emir Çekem'in bulunduğu İskenderiye Hapishanesi'ne yollad $1 .{ }^{50}$

Sultan Ferec, muhalif ve muktedir birçok emirin aynı hapishanede tutuklu bulunmasının bir risk oluşturduğunu düşünerek 20 Şubat 1403'te Emir Akberdi ve Emir Tanbek nezaretinde memâlik-i sultandan 30 memlûku, bu emirleri farklı hapishanelere intikal ettirmek üzere görevlendirdi. ${ }^{51}$ Emir Çekem, Emir Nevrûz, Emir Kanıbay ve Emir Sûdûn Tâz, Akdeniz üzerinden Bilâd-1 Şam'a sevk edildiler. Emir Çekem, Trabulus'a bağlı Hısnü'l-Ekrad'a; Emir Nevrûz ve Kanıbay, Dımaşk'a bağlı Subeybe Kalesi'ne ve Emir Sûdûn Taz ise Merkab Kalesi'ne konuldular. Bir süre sonra güvenlik gerekçesiyle Emir Çekem, Hisnü'l-Ekrad'dan alınarak düşmanı Sûdûn Taz'ın bulunduğu Merkab Kalesi'ne gönderildi. ${ }^{52} \mathrm{Bu}$ intikal işlemi 211 Mayıs 1403 tarihleri arasında tamamlanmıştı. Emir Çekem, hapsedildiği 26 Mayıs 1402'den Hısnü'l-Ekrad'a havale edildiği 2 Mayıs 1403 tarihine kadar yaklaşık bir yıl İskenderiye Hapishanesi'nde kalmıştı.

\section{4- Emir Çekem'in İsyanları}

\section{1. İlk İsyanı ve Kahire'yi Ele Geçirme Teşebbüsü}

Emir Çekem'in Merkab Kalesi'nde hapis bulunduğu dönemlerde Safed'in eski nâibi Emir Dokmak el-Muhammedî, Dulkadirli Ali Bey ile ittifak ederek Halep'e saldırmıştı. ${ }^{53}$ Dokmak ve Ali Bey önünde tutunamayan Halep nâibi Emir Akboğa el-Cemâlî el-Etruş ve diğer emirler şehri terk ederek kaçmak zorunda kalmışlardı. Sultan Ferec, Halep'in işgali üzerine Trabulus nâibi Emir Demirtaş'ı yeni Halep nâibi olarak atadı. Demirtaş'ın Halep'e atanmasıyla boşalan Trabulus niyâbeti makamına Safed nâibi Emir Şeyh el-Masartan getirildi. Safed'e ise Dımaşk emirlerinden olan Emir Bektimur el-Çalık atandı. Sultan, olası bir ittifaka karşı Emir İnal Bay el-Memurî’yi hapiste bulunan Çekem'i ve Nevrûz'u öldürmek üzere bölgeye gönderdi. ${ }^{54}$

Halep'in yeni nâibi Emir Demirtaş, Dokmak ve Ali Bey ile yapacağı mücadelede kendisine katkı sağlayacakları düşüncesiyle o sırada Merkab Kalesi'nde hapis bulunan Emir Çekem, Emir Nevrûz ve Emir Sûdûn Taz'1 Ocak-Şubat 1404'te serbest biraktı. ${ }^{55}$ Çekem, Nevrûz ve Sûdûn Taz serbest kaldıktan hemen sonra Emir Demirtaş saflarında Emir Dokmak'a karşı savaşmak üzere Halep'e gittiler. Emir Çekem, Halep'e geldikten sonra Halep gelirlerinin paylaşılması hususunda Demirtaş ile fikir ayrılı̆̆ yaşadı ve ondan çekindiğinden Türkmenlerin safına katıld1. ${ }^{56}$ Emir Sûdûn el-Celeb, Kerek nâibi Emir Cumuk ve diğer emirler de Çekem'e katıldılar. ${ }^{57} \mathrm{Bu}$ ittifaka Türkmen emirlerinden İlyas olarak meşhur olan Bazoğlu Faris de destek verdi. Çekem ve Bazoğlu, Aralık 1404'te Demirtaş ile Halep önlerinde yaptı̆̆ 1 savaş1 kaybederek Antakya'ya çekildiler. ${ }^{58}$ Demirtaş; Çekem ve Bazoğlu'nu yakalamak üzere Antakya'yı kuşattı. ${ }^{59}$

\footnotetext{
${ }^{50}$ İbn Tağriberdî, en-Nücûmu'z-Zâhire, C. 12, s. 231; Sayrafî, a.g.e., C. 2, s. 143, 161.

${ }^{51}$ Makrizî, a.g.e., C. 6, s. 87; İbn Tağrıberdî, en-Nücûmu'z-Zâhire, C. 12, s. 232; Sayrafî, a.g.e., C. 2, s. 162.

${ }^{52}$ Makrizî, a.g.e., C. 6, s. 88; İbn Hacer, a.g.e., C. 2, s. 203, 232; İbn Tağrıberdî, en-Nücûmu'z-Zâhire, C. 12, s. 232; a. mlf., el-Menhelü's-Sâfí, C. 4, s. 316; Sayrafî, a.g.e., C. 2, s. 163.

${ }^{53}$ Makrizî, a.g.e., C. 6, s. 104; İbn Hacer, a.g.e., C. 2, s. 261; İbn Tağrıberdî, en-Nücûmu'z-Zâhire, C. 12, s. 235; Sayrafî, a.g.e., C. 2, s. 185.

${ }^{54}$ Makrizî, a.g.e., C. 6, s. 104; İbn Tağrıberdî, en-Nücûmu'z-Zâhire, C. 12, s. 235.

${ }^{55}$ Makrizî, a.g.e., C. 6, s. 105; İbn Tağriberdî, en-Nücûmu'z-Zâhire, C. 12, s. 235, 238; a. mlf., el-Menhelü's-Sâfî, C. 4 , s. $316 \mathrm{vd}$.

${ }^{56}$ İbn Hacer, a.g.e., C. 2, s. 262; İbn Tağriberdî, en-Nücûmu'z-Zâhire, C. 12, s. 240.

57 İbn Tağriberdî, en-Nücûmu'z-Zâhire, C. 12, s. 240.

${ }^{58}$ Makrizî, a.g.e., C. 6, s. 118; İbn Hacer, a.g.e., C. 2, s. 269; İbn Tağrıberdî, el-Menhelü's-Sâfî, C. 4, s. 317.

${ }_{59}$ Makrizî, a.g.e., C. 6, s. 118; İbn Hacer, a.g.e., C. 2, s. 262, 269; İbn Tağriberdî, el-Menhelü's-Sâfí, C. 4, s. 317; Refet Yinanç, Dulkadir Beyliği, TTK., Ankara 1989, s. 36.
} 
Devadâr Emir Yeşbek el-Osmanî, sultanın eniştesi olan Emir İnal Bay ile anlaşamadığından sultana ait 200.000 dirhem nakit parayı zimmetine geçirdikten sonra Kahire'den kaçarak Gazze'ye yerleşmişti. ${ }^{60}$ Dokmak, Emir Demirtaş'a mağlup olduktan sonra Dımaşk nâibi Emir Şeyh Mahmudî’nin daveti üzerine Dımaşk'a gitmişti. Şeyh Mahmudî, Gazze'de bulunan Emir Yeşbek'i de Dımaşk'a davet etti. ${ }^{61}$ Sultan Ferec, Bilâd-1 Şam'daki bu gelişmeler üzerine Emir Nevrûz'u ve Timurboğa el-Meştûb'u Kahire'ye davet etti. Dımaşk nâibi Şeyh Mahmudî’ye haber göndererek Çekem'e âmân verdiğini ve onun Türkmen ittifakından koparılmasını emretti. Emir Çekem'i affettiğine dair âmân belgesini ise Aralık 1404 'te Emir Tugay Timur'a ${ }^{62}$ vererek onu Halep'e yolland. ${ }^{63}$ Dımaşk emirlerine yakalanmamak için deniz yoluyla bölgeye yönelen Tugay Timur, o sırada Antakya'da bulunan Çekem'e belgeyi verdi. Sultan, Çekem'e Mısır'a dönmesini ya da emekliye ayrılarak Kudüs veya Trabulus'ta ikamet etmesini teklif ediyordu. ${ }^{64}$ Emir Çekem, sultanın ikinci teklifini kabul ederek Trabulus'a gitti. ${ }^{65}$ Fakat Trabulus nâibi Şeyh Süleymanî tarafından pek de hoş karşılanmadı. Kısa süre sonra Süleymanî ile savaşan Çekem, onu esir ederek Sehyun Kalesi'ne hapsetti. ${ }^{66}$ Şubat 1405 'te ise Sultan Ferec adına Trabulus'ta okutulan hutbeyi kaldırmak sûretiyle isyan etmiş oldu. ${ }^{67}$ Sehyun nâibi Emir Bayezir'den Süleymanî'yi öldürmesini istediyse de Bayezir onun bu teklifini reddetti ve Süleymanî'yi hapisten çıkararak onunla Çekem'e karşı ittifak etti. ${ }^{68}$ Çekem, Mısır'1 ele geçirmek üzere harekete geçeceğinden geçiş güzergâhının güvenliğinin sağlanması hususunda Gazze nâibi ile Cerm'deki urban emiri Ömer b. Fazıl'a haber yollad $1 .{ }^{69}$ Trabulus'un Çekem'in hâkimiyetine girişi üzerine Dımaşk nâibi Şeyh Mahmudî, Emir Kanıbay'ı Çekem'e yollayarak isyanın ayrıntılarını ve yol haritasını belirlemek üzere onu Dımaşk'a davet etti. ${ }^{70}$

Çekem, Trabulus'tan ayrıldıktan sonra Hama'yı ele geçirdi. Hama nâibi Emir Allan'1 da yanına alarak Demirtaş ile savaşmak üzere Halep'e gitti. ${ }^{71}$ Şubat 1405 'te, Demirtaş ile Halep önlerinde yaptı̆̆ı savaşı kazanan Çekem, Demirtaş'ı Ayas'a sığınmaya mecbur etti. ${ }^{72}$ Trabulus'tan sonra Halep'i de ele geçiren Çekem, "Melikü'l-Âdil" lakabını alarak kendisini sultan ilan etti. ${ }^{73}$ Yanında bulunan Hama nâibi Emir Allan'a Demirtaş'ın iktaını verdikten sonra onu kendi adına yeniden Hama nâibi olarak atadı. ${ }^{74}$ Ayrıca, Bire ve Suruc'u işgal eden Döğer Türkmenlerinden Yağmur ed-Döğerî'yi yakalamak üzere adamlarından Emir Sûdûn el-Hâcib'i Firat boylarına yolladı. Sûdûn, Yağmur Bey'i esir ederek 6.000 deve ve 10.000 koyunla Halep'e döndü. ${ }^{75} \mathrm{Bu}$ hadise Emir Çekem'in kendisini sultan ilan ettikten sonraki ilk askeri başarısıdır. Çekem' in saltanatını tanıyan Halep, Trabulus ve Hama' da yaşayan Memlûklu halkı, Timur'un bölgeye gelişinden beri ciddi iktisadi ve asayiş problemleriyle karşılaştıklarından oldukça yıpranmışlardı. Çekem'in halka iyi muamele etmesi bu bölgede yaşayan halk

\footnotetext{
${ }^{60}$ Makrizî, a.g.e., C. 6, s. 117; İbn Hacer, a.g.e., C. 2, s. 291; İbn Tağrıberdî, en-Nücûmu'z-Zâhire, C. 12, s. 239.

${ }^{61}$ İbn Hacer, a.g.e., C. 2, s. 291; İbn Tağriberdî, en-Nücûmu'z-Zâhire, C. 12, s. 241; Sayrafî, a.g.e., C. 2, s. 197.

${ }^{62}$ Sayrafî̀, bu ismi Altunboğa Şekir olarak kaydetmektedir. Bkz. Sayrafî, a.g.e., C. 2, s. 197.

${ }^{63}$ İbn Tağrıberdî, en-Nücûmu'z-Zâhire, C. 12, s. 239; Refet Yinanç, a.g.e., s. 36; Esra Çıplak, a.g.t., s. 27.

${ }^{64}$ Makrizî, a.g.e., C. 6, s. 118.

${ }^{65}$ A.g.e., C. 6, s. 119.

${ }^{66}$ A.g.e, C. 6, s. 119.

${ }^{67}$ Makrizî, a.g.e. C. 6, s. 119; İbn Hacer, a.g.e., C. 2, s. 296.

${ }^{68}$ Makrizî, a.g.e., C. 6, s. 119.

${ }^{69}$ A.g.e., C. 6, s. 119.

${ }^{70}$ A.g.e., C. 6, s. 119

${ }^{71}$ A.g.e., C. 6, s. 120.

${ }_{72}^{72}$ Makrizî, a.g.e., C. 6, s. 120; İbn Tağriberdî, el-Menhelü's-Sâfî, C. 4, s. 317.

${ }^{73}$ Makrizî, a.g.e., C. 6, s. 123; İbn Hacer, a.g.e., C. 2, s. 263; İbn Tağrıberdî, en-Nücûmu'z-Zâhire, C. 12, s. 241.

${ }^{74}$ Makrizî, a.g.e., C. 6, s. 120; İbn Tağriberdî, en-Nücûmu'z-Zâhire, C. 12, s. 240.

${ }^{75}$ Makrizî, a.g.e., C. 6, s. 122; İbn Tağriberdî, el-Menhelü's-Sâfî, C. 4, s. 317.
} 
tarafından kısa sürede sevilmesine neden oldu. Bölge halkı Çekem'i "Çekem, Çekem! Ve ma zelem (Çekem, Çekem! Artık yoktur zulüm)" tezahüratlarıyla karşılıyordu. ${ }^{76}$

Dımaşk nâibi Şeyh Mahmudî, Çekem'in Trabulus'u ele geçirmesi üzerine bir taraftan onu Dımaşk'a davet etmiş diğer taraftan da Halep nâibi Demirtaş'a Çekem ile yapacağ 1 savaşta destek olacağına dair elçi göndererek ikili bir politika takip etmişti. ${ }^{77}$ Şeyh Mahmudî, Çekem'in Demirtaş'ı mağlup ederek saltanatını ilan etmesi üzerine devadârı Şahin'i Çekem'e yolladı ve Çekem'e bağlılığını bildirerek onu yeniden Dımaşk'a davet etti. Ardından da Sultan Ferec'e bağlı olduğunu ilân eden Safed nâibi Bektimur el-Çalık'1 yakalamak üzere Emir Tımraz enNâsırî ve Emir Çerkes el-Kasımî’yi bir grup askerle Safed'e yolladı. Şeyh Mahmudî, Tımraz ve Çerkes'in başarısız olmaları üzerine bizatihi Safed seferine çıktı ve 18 Şubat 1405 'te mancınıklarla Safed'i kuşatmaya başladi. ${ }^{78}$

Emir Çekem, Dımaşk ve Kahire emirlerinin biatlarını almadan saltanat makamını elde edemeyeceğini ve saltanatının meşru olmayacağını biliyordu. Halep Kale nâibliği görevine Emir Şerafeddin Musa b. Yıldık'ı ve diğer makamlara çeşitli görevlileri atadıktan sonra 13 Mart 1405 'te beraberinde Emir Kanıbay, Emir Tağrıberdi el-Kaçgarî ve kalabalık bir ordu olduğu halde Dımaşk'a gitmek üzere Halep'ten çıktı. ${ }^{79}$

Dımaşk nâibi Şeyh ve Emir Yeşbek, Safed'i ele geçirmeyi başaramadan yaralı bir şekilde Dımaşk'a dönmüşlerdi. ${ }^{80}$ Şeyh, Dımaşk'a döndükten hemen sonra o sırada Dımaşk’ta göz hapsinden bulunan Bağdat hâkimi Sultan Ahmed b. Üveys ve Karakoyunlu Beyi Kara Yusuf'u Emir Tımraz, Emir Bekçe, Sûdûn el-Hamzavî, Yelboğa en-Nâsırî, İnal Hatib ve Çerkez elMusarî eşliğinde büyük bir ordu ile Gazze'yi ele geçirmek üzere yolladı. Şeyh ve Yeşbek'in memlûkleri dışında kimse Mısır'ın ele geçirilmesini istemiyordu. ${ }^{81}$ Dımaşk kuvvetlerinin Gazze'ye hareketinden kısa süre sonra Emir Çekem, 25 Mart 1405'te mahiyetiyle birlikte Dımaşk'a girdi. ${ }^{82}$ Saltanat alametleri kuşanan Çekem, başta Şeyh ve Yeşbek olmak üzere diğer Dımaşk emirleri tarafından büyük bir törenle karşılandı. Kale meydanına indikten sonra kendisi için hazırlanan tahta sağında Yeşbek, solunda Şeyh olduğu halde oturdu. ${ }^{83}$ Emirlere bir dizi bağışlarda bulunduktan sonra çeşitli atamalar yaptı. Şeyh ve Yeşbek dışındaki diğer emirler, Çekem'in saltanatına karşı çıksalar da bunu açığa vurmaktan çekiniyorlardı ${ }^{84}$ Çekem, 27 Mart 1405 'te Dımaşk'ta Sultan Ferec adına okunan hutbeyi iptal ederek hutbenin sadece halife adına okunmasını sağladı. ${ }^{85} \mathrm{Bu}$ şekilde, Safed hariç olmak üzere Bilâd-ı Şam'ın tamamı Emir Çekem'in hâkimiyeti altına girmiş oldu. Çekem, Şeyh ve Yeşbek arasında yapılan anlaşmaya göre taraflar ordularını takviye ettikten kısa süre sonra Kahire'yi ele geçirmek üzere harekete geçeceklerdi.

Emir Çekem, 29 Mart 1405'te ordularını takviye etmek üzere Dımaşk'tan ayrılarak Trabulus'a gitti. ${ }^{86}$ Dımaşk nâibi Şeyh, haremini ve hazinesini Subeybe Kalesi'ne yolladıktan sonra 20 Mayıs 1405 'te Yeşbek el-Osmanî ve Kara Yusuf ile birlikte Kahire'ye gitmek üzere

\footnotetext{
${ }^{76}$ İbn Tağriberdî, en-Nücûmu'z-Zâhire, C. 12, s. 240.

${ }^{77}$ A.g.e., C. 12 , s. 241.

${ }^{78}$ A.g.e., C. 12, s. 242.

${ }^{79}$ Makrizî, a.g.e., C. 6, s. 123; İbn Tağriberdî, en-Nücûmu'z-Zâhire, C. 12, s. 242; a. mlf., el-Menhelü's-Sâfì, C. 4, s. 317.

${ }^{80}$ İbn Tağriberdî, en-Nücûmu'z-Zâhire, C. 12, s. 243.

${ }^{81}$ A.g.e, C. 12, s. 244.

${ }^{82}$ Makrizî, a.g.e., C. 6, s. 123.

${ }^{83}$ İbn Tağriberdî, en-Nücûmu'z-Zâhire, C. 12, s. 243.

${ }^{84}$ A.g.e, C. 12, s. 244.

${ }^{85}$ Makrizî, a.g.e., C. 6, s. 124; İbn Tağrıberdî, en-Nücûmu'z-Zâhire, C. 12, s. 244.

${ }^{86}$ Makrizî, a.g.e., C. 6, s. 123; İbn Tağrıberdî, en-Nücûmu'z-Zâhire, C. 12, s. 243.
} 
Dımaşk'tan çıktı. ${ }^{87}$ Ordu, Harbe mevkiine ulaştığında Emir Şeyh; Kara Yusuf ve Yeşbek’i direnen Bektimur el-Çalık üzerine yeniden Safed'e gönderdi. ${ }^{88} \mathrm{Bu}$ sirada Çekem adına Hama nâibliği görevini yürüten Emir Allan, Sultan Ferec'e bağlı olduğunu ilân ederek Çekem'den ayrıldı. ${ }^{89}$ Allan, Subeybe'de bulunan ve Sultan Ferec'e bağlılığını açıklayan Trabulus eski nâibi Emir Süleymanî'ye katılmak üzere Subeybe'ye gitti. ${ }^{90}$ Bunun üzerine Çekem, Allan'ı tedip etmek üzere Emir Hüseyin b. Emir Esed el-Hâcib önderliğinde bir orduyu Subeybe'ye gönderdi. ${ }^{91}$ Emir Hüseyin, Subeybe'yi yaklaşık on gün kuşattıysa da başarılı olamadı. ${ }^{92} \mathrm{Bu}$ gelişmeler, Ferec adına Safed'de Çekem taraftarlarına direnen Emir Bektimur el-Çalık'ın direncini arttırıyordu. Kara Yusuf ve Yeşbek, Safed'de bir kez daha başarısızlığa uğradıktan sonra Emir Şeyh ile buluşmak üzere Taberiye bölgesine çekilmek zorunda kaldılar. ${ }^{93}$ Emir Şeyh tarafından Gazze'ye gönderilen Çekem öncü kuvvetleri Gazze'yi ele geçirdikten sonra 1 Haziran 1405 'te Kahire'ye doğru yola çıktılar. ${ }^{94}$ Öncü kuvvetlerin hareketinden bir gün sonra Çekem, Şeyh ve Yeşbek Gazze'ye ulaştılar. Emir Çekem burada Gazze nâibi Hayır Beyi görevinden alarak yerine Emir Altuboğa el-Osmanî’yi atadı. ${ }^{95}$

Sultan Ferec, Emir Çekem'in Safed haricindeki Bilâd-1 Şam niyabetlerine hâkim olarak saltanatını ilan etmesi üzerine Bilâd-ı Şam seferine çıkmaya mecbur kaldı. 5.000 kişilik bir kuvvet toplayan sultan, bir kısmını borçlanmak suretiyle temin ettiği asker başı 500 dirhem harcırah ve 45 miskal yem-gıda değerindeki toplam 2.500 .000 dinarlık sefer bütçesini oluşturduktan sonra 1 Haziran 1405 'te öncü birliklerini Gazze'ye yollad1. ${ }^{96}$ Kendisi ise Reydaniye'de konuşlandı. Ardından Bilbis üzerinden Saidiye'ye ulaştı. Burada iken Çekem, Şeyh ve Yeşbek sultana bir mesaj yollayarak "O sırada Kahire'de bulunan sâbık Halep nâibi Emir Demirtaş ile Yeşbek'le aralarında husumet bulunan sultanın eniştesi Emir İnal Bay'ın Kahire'den kovulması şartıyla" isyanı sona erdireceklerini bildirdiler. ${ }^{97}$ Safed nâibi Bektimur, Hama nâibi Allan ve Trabulus nâibi Süleymanî Sultan Ferec safında yer aldıkları için Çekem ve Şeyh, zaman kazanmak amacıyla sultana böyle bir mektup göndermiştiler. Bu yazışma süresince Kara Yusuf, 3.000 atlı ve 400 Türkmen askeri toplamayı başararak Gazze'ye ulaşmıştı. ${ }^{98}$ Sultan Ferec, muhaliflerin vakit kazanmaya çalıştıklarını anladığından halife ve dört içtihat kadısının da yer aldığı ordusuyla harekete geçti ve iki ordu Saidiye'de karşılaştı. Yapılan savaşı Çekem'in ordusu kazandı ve Ferec, ağırlıklarını savaş alanında bırakarak Kahire'ye kaçmak zorunda kaldı. ${ }^{99}$ Çekem; halife, dört ictihat kadısı, Emir Şahin el-Efrum, Gazze nâibi Emir Hayır Bey ve üç yüz askeri esir etmeyi başararak Ferec'in peşinden tahtı elde etmek üzere Kahire'ye hareket etti. ${ }^{100} 12$ Haziran 1405 'te Çekem ve ordusu Reydaniye'ye gelerek konuşlandılar. Kahire halkı kale kapılarını, esnaf dükkânlarını kapatmışlardı. ${ }^{101}$ Çekem kuvvetleri Kalatü'l-cebel yakınlarındaki Dâr-1 Ziyafe'de Ferec'in kuvvetleriyle giriştikleri çatışmada başarısız oldular. Emir Yelboğa en-Nâsırî, Esen Bay et-Türkmanî, Sûdûn el-Yusufî,

\footnotetext{
${ }^{87}$ Makrizî, a.g.e., C. 6, s. 128; İbn Tağrıberdî, en-Nücûmu'z-Zâhire, C. 12, s. 244.

${ }^{88}$ İbn Tağrıberdî, en-Nücûmu'z-Zâhire, C. 12, s. 244.

${ }^{89}$ Makrizî, a.g.e., C. 6, s. 127; İbn Tağrıberdî, en-Nücûmu'z-Zâhire, C. 12, s. 244.

${ }^{90}$ Makrizî, a.g.e., C. 6, s. 127; İbn Tağrıberdî, en-Nücûmu'z-Zâhire, C. 12, s. 245.

${ }^{91}$ Makrizî, a.g.e., C. 6, s. 127.

${ }_{92}$ A.g.e, C. 6, s. 127.

93 Makrizî, a.g.e., C. 6, s. 129; İbn Tağrıberdî, en-Nücûmu'z-Zâhire, C. 12, s. 245.

${ }^{94}$ Makrizî, a.g.e., C. 6, s. 130; İbn Tağrıberdî, en-Nücûmu'z-Zâhire, C. 12, s. 246.

95 Makrizî, a.g.e., C. 6, s. 130; İbn Tağrıberdî, en-Nücûmu'z-Zâhire, C. 12, s. 247.

96 İbn Tağrıberdî, en-Nücûmu'z-Zâhire, C. 12, s. 246.

${ }^{97}$ Makrizî, a.g.e, C. 6, s. 130; İbn Tağriberdî, en-Nücûmu'z-Zâhire, C. 12, s. 247; Esra Çıplak, a.g.t., s. 28.

98 İbn Tağriberdî, en-Nücûmu'z-Zâhire, C. 12, s. 248; Sayrafî, a.g.e., C. 2, s. 203.

${ }^{99}$ Makrizî, a.g.e., C. 6, s. 131-132; İbn Tağriberdî, en-Nücûmu'z-Zâhire, C. 12, s. 248; a. mlf., el-Menhelü's-Sâfì, C. 4, s. 318; Esra Çıplak, a.g.t., s. 29.

${ }^{100}$ Makrizî, a.g.e., C. 6, s. 131-132; İbn Tağrıberdî, en-Nücûmu'z-Zâhire, C. 12, s. 248 vd.

101 İbn Tağrıberdî, en-Nücûmu'z-Zâhire, C. 12, s. 249; Esra Çıplak, a.g.t., s. 29.
} 
İnal Hatib ve Cumuk'un temsil ettiği kuvvetler Sultan Ferec safına geçince Çekem'in ordusu dağıldı. ${ }^{102}$ Özellikle sultanın memlûklerinin (memâlik-i sultan) Çekem'e katılmaması ve yukarıda adı geçen emirlerin saf değiştirmeleri nedenleriyle Çekem, Kahire'ye giremedi. Gazze önlerinde esir edilen Halife ve dört içtihat kadısı serbest bırakıldıktan sonra Çekem ve Şeyh, Kahire önlerinden ayrılarak Bilâd-1 Şam'a döndüler. ${ }^{103}$ Bu savaş, her iki tarafın at, deve, silah ve para yönünden ciddi kayıplara uğradığı bir savaştır.

\section{2. İkinci İsyanı}

\subsection{1. İsyan Öncesi Gelişmeler}

Sultan Ferec, Bilâd-1 Şam'da kaybolan devlet otoritesini yeniden tesis amacıyla savaşı kazandıktan hemen sonra bazı yeni atamalar yaptı. Şöyle ki; Şeyh Mahmudî yerine Dımaşk’a Emir Nevrûz el-Hâfızî, Çekem yerine Halep'e Emir Allan el-Yahyavî atandılar. ${ }^{104}$ Emir Dokmak el-Muhammedî, Hama'ya; Emir Bektimur el-Çalık Trabulus'a; Emir Bektimur elRüknî ise Safed niyâbetleri görevine getirildiler. ${ }^{105}$

Çekem, Halep'ten ayrıldıktan sonra, önceki dönemlerde Halep kale nâipliği görevini yürütmüş olan İbn Şehrî, Beyzaviye Türkmenleri ile birlikte Halep'i ele geçirmişti. Halep'te Çekem adına bulunan yöneticilerle İbn Şehrî, Emir Yûnûs'u Halep yönetimine getirmişlerdi. Daha sonra Nuayroğlu el-Acl önderliğindeki Araplarla Bazoğlu Faris liderliğindeki Türkmenler

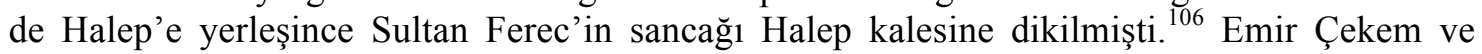
Şeyh, başarısız Kahire kuşatmasının ardından Karakoyunlu Kara Yusuf ve Celâyirli Ahmed b. Üveys ile birlikte Dımaşk'a ulaşmışlardı. Çekem, Halep'i kurtarmak üzere Nuayroğlu el-Acl üzerine gitmek istemiş; fakat Şeyh ve diğerlerinin muhalefeti üzerine Trabulus'a çekilmişti. ${ }^{107}$ Kara Yusuf ve Ahmed bu gelişme üzerine ülkelerine dönmüş, ${ }^{108}$ Şeyh ise Sultan Ferec'e yazdığı bir mektup ile Dımaşk niyâbeti makamını yeniden talep etmiş; fakat bu talebi reddedilince Subeybe'ye çekilmek zorunda kalmıștı. ${ }^{109}$ Şeyh yerine Dımaşk niyâbetine atanan Emir Nevrûz el-Hafızî, 19 Ağustos 1405 tarihinde herhangi bir mukavemetle karşılaşmadan Dımaşk'a girdi. ${ }^{110}$ Nevrûz'un Dımaşk'ta göreve başladığı bu dönemde Sultan Ferec, emirlerin baskısından bunaldığından Ağustos 1405'in sonlarında saltanat makamını terk ile yaklaşık 69 gün boyunca Kahire'de gizlendi. ${ }^{111}$ Onun makamını terk etmesinin ardından yerine kardeşi Abdülaziz yeni Memlûk sultanı ilân edildi. ${ }^{112}$ Kahire'deki bu gelişme Bilâd-1 Şam'da sağlanmaya çalışılan istikrarı bir kez daha akamete uğrattı.

102 İbn Hacer, a.g.e., C. 2, s. 295 vd; İbn Tağrıberdî, en-Nücûmu'z-Zâhire, C. 12, s. 250.

${ }^{103}$ Makrizî, a.g.e., C. 6, s. 131-132; İbn Hacer, a.g.e., C. 2, s. 293; İbn Tağrıberdî, en-Nücûmu'z-Zâhire, C. 12, s. 250; a. mlf., el-Menhelü's-Sâfí, C. 4, s. 318; Sayrafî, a.g.e., C. 2, s. 204; Esra Çıplak, a.g.t., s. 30; Asri Çubukçu, "Ferec", DIA , C. 12, İstanbul 1995, s. 370-371.

${ }^{104}$ Makrizî, a.g.e., C. 6, s. 132-134; İbn Tağrıberdî, en-Nücûmu'z-Zâhire, C. 12, s. 250-251; a. mlf., el-Menhelü'sSâfì, C. 4 , s. 318 vd.

${ }^{105}$ Makrizî, a.g.e., C. 6, s. 134; İbn Tağrıberdî, en-Nücûmu'z-Zâhire, C. 12, s. 251; a. mlf., el-Menhelü's-Sâfí, C. 4, s. 319.

${ }_{106}^{106}$ Makrizî, a.g.e., C. 6, s. 133; İbn Tağrıberdî, en-Nücûmu'z-Zâhire, C. 12, s. 251.

${ }^{107}$ Makrizî, a.g.e., C. 6, s. 139; İbn Tağrıberdî, en-Nücûmu'z-Zâhire, C. 12, s. 252.

108 İbn Tağriberdî, en-Nücûmu'z-Zâhire, C. 12, s. 250-252.

${ }^{109}$ Makrizî, a.g.e., C. 6, s. 139; İbn Hacer, a.g.e., C. 2, s. 316; İbn Tağrıberdî, en-Nücûmu'z-Zâhire, C. 12, s. 252253.

${ }^{110}$ Makrizî, a.g.e., C. 6, s. 139; İbn Hacer, a.g.e., C. 2, s. 316; İbn Tağrıberdî, en-Nücûmu'z-Zâhire, C. 12, s. 253.

${ }^{111}$ Makrizî, a.g.e., C. 6, s. 142-143; İbn Hacer, a.g.e., C. 2, s. 322; İbn Tağrıberdî, en-Nücûmu'z-Zâhire, C. 12, s. 256-258; Sayrafî, a.g.e., C. 2, s. 212; İbn Îyâs, a.g.e., s. 304; İsmail Yiğit, Memlûkler 648-923/1250-1517, Kayıhan Yay., İstanbul 2015, s. 108; Esra Çıplak, a.g.t., s. 32 vd.

${ }_{112}$ Makrizî, a.g.e., C. 6, s. 142-143; İbn Hacer, a.g.e., C. 2, s. 319; İbn Tağrıberdî, en-Nücûmu'z-Zâhire, C. 13, s. 3; İbn Îyâs, a.g.e., s. 304; Esra Çıplak, a.g.t., s. 33. 
Emir Çekem, Sultan Ferec'in Kahire'de gizlenmesi ve yerine kardeşi Abdülaziz'in geçişi üzerine Emir Şeyh ile ittifak ederek Dımaşk nâibi Emir Nevrûz'a saldırdı. Nevrûz, Dımaşk’1 terk ile Trabulus nâibi Emir Bektimur'a sığınmak zorunda kalınca Şeyh, Çekem'e biat etti. ${ }^{113}$ Çekem ve Şeyh, Nevrûz'u takip ile Trabulus'a gidince Bektimur ve Nevrûz, Hama'ya çekildiler. Bu şekilde Trabulus yeniden Emir Çekem'in hâkimiyetine girdi. ${ }^{114}$ Çekem yerine Halep niyabetine atanmış olan Emir Allan, Ferec tahttan çekilmeden önce Halep'teki görevine başlamıştı. Emir Bektimur ve Nevrûz'un Çekem önünden çekilerek Hama'ya sığınmaları üzerine Allan, bu iki emire destek vermek üzere Hama'ya gitti. ${ }^{15}$ Onun Hama'ya gelişini firsat bilen Hama nâibi Dokmak el-Muhammed'i, Halep'i ele geçirdi. ${ }^{116}$ Emir Çekem, hoşdaşı Dokmak el-Muhammedî üzerine yürüyüp onu öldürdükten sonra Nevrûz ve Bektimur ile mücadele için Hama'ya yöneldi. Hama civarında yapılan savaşta Nevrûz ve Bektimur'u mağlup ettikten sonra Kahire'ye bir mektup yollayarak Dımaşk ve Trabulus'u ele geçirdiğini bildirdi. ${ }^{117}$ Atabekü'l-asâkir Baybars, bu gelişme üzerine 4 Kasım 1405'te Sultan Abdülaziz'in lalası Tavaşi Şahin el-Hasenî önderliğindeki on kişilik bir heyeti Çekem ve Şeyh'i Kahire'ye getirmek üzere bölgeye gönderdi. ${ }^{118}$ Heyetin bölgeye varışından kısa süre sonra Sultan Ferec, 28 Kasım 1405'te ikinci kez Memlûklu tahtına oturdu. ${ }^{119}$ Ferec, Bilâd-1 Şam'daki durumun nezaketine binaen 28 Kasım 1405 tarihli atama kararnâmesiyle Emir Çekem'i, Emir Allan yerine Halep; Emir Şeyh'i ise Nevrûz yerine Dımaşk niyâbetlerine atadı. ${ }^{120}$

Emir Çekem, Trabulus'ta iken Halep niyâbetine atandığına dair resmi yazı kendisine ulaşmıştı. Emir Nevrûz, Hama önlerinde Çekem'e mağlup olduktan sonra Emir Allan ile birlikte Halep'e yerleşmişti. Çekem, Dımaşk nâibi Şeyh Mahmudî ile birlikte yeni görev bölgesine doğru hareket etti. Maarra'ya ulaştığında Emir Nevrûz'dan Çekem'in Halep'e atandığından haberi olmadığı için şehirden ayrılmadığını belirten özür mektubu ulaştı. Kısa süre sonra ise Allan ile birlikte Halep'ten ayrıldı. ${ }^{121}$ Nevrûz'un Halep'ten ayrılmasından sonra Çekem, herhangi bir savaşa gerek kalmadan şehirdeki görevine başladı. Sultan Ferec, Çekem'in görevine başlamasından hemen sonra ona Trabulus niyâbeti görevine getirildiğine dair bir emirnâme (misal-i Sultanî) göndererek Halep ve Trabulus niyâbetlerini Çekem'in uhdesinde birleştirdi. ${ }^{122}$ Trabulus nâibi Emir Bektimur el-Çalık, Dımaşk emir-i kebirliği kadrosuna çekildi. Nevrûz ise emekliliğe sevk edilerek Kudüs’te ikamete mecbur edildi. ${ }^{123}$

\subsection{2. İsyanı}

Emir Çekem, Halep'e atandıktan kısa süre sonra Kudüs'te ikamet eden Emir Nevrûz ve Dımaşk emir-i kebirliği kadrosunda bulunan Trabulus eski nâibi Emir Bektimur ile yazışarak onları kendisine katılmaya davet etti. Nevrûz ve Bektimur, Çekem'in davetine uyarak Halep'e gittiler. ${ }^{124}$ Dımaşk nâibi Emir Şeyh, Sultan Ferec'e bağlılı̆̆ını bildirerek ittifaka katılmadı. Şeyh'in ittifaka destek vermemesi üzerine Bektimur, Çekem'den ayrılarak Dımaşk'a sığındı. Sultan Ferec, Çekem ile birlikte Halep'te bulunan Nevrûz'a Şubat-Mart 1406'da bir resmi yazı

\footnotetext{
${ }^{113}$ Makrizî, a.g.e., C. 6, s. 147; İbn Tağrıberdî, en-Nücûmu'z-Zâhire, C. 13, s. 5.

${ }_{114}^{114}$ Makrizî, a.g.e., C. 6, s. 147; İbn Hacer, a.g.e., C. 2, s. 320; İbn Tağrıberdî, en-Nücûmu'z-Zâhire, C. 13, s. 5.

${ }_{115}$ Makrizî, a.g.e., C. 6, s. 147; İbn Tağrıberdî, en-Nücûmu'z-Zâhire, C. 13, s. 5.

${ }^{116}$ İbn Tağriberdî, en-Nücûmu'z-Zâhire, C. 13, s. 13; a. mlf., el-Menhelü's-Sâfí, C. 4, s. 319.

${ }^{117}$ Makrizî, a.g.e., C. 6, s. 147; İbn Tağrıberdî, en-Nücûmu'z-Zâhire, C. 13, s. 13.

118 Makrizî, a.g.e., C. 6, s. 147; İbn Tağriberdî, en-Nücûmu'z-Zâhire, C. 13, s. 5-6; Sayrafî, a.g.e., C. 2, s. 213.

119 İbn Tağrıberdî, en-Nǘcumu'z-Zâhire, C. 13, s. 11; Sayrafî, a.g.e., C. 2, s. 214; Esra Çıplak, a.g.t., s. 33.

${ }^{120}$ Makrizî, a.g.e., C. 6, s. 150; İbn Hacer, a.g.e., C. 2, s. 321; İbn Tağrıberdî, en-Nücûmu'z-Zâhire, C. 13, s. 12; a. mlf., el-Menhelü's-Sâfí, C. 4, s. 320; Sayrafî, a.g.e., C. 2, s. 216; Esra Çıplak, a.g.t., s. 34.

${ }^{121}$ Makrizî, a.g.e., C. 6, s. 152; İbn Tağriberdî, en-Nücûmu'z-Zâhire, C. 13, s. 13.

122 İbn Tağnıberdî, en-Nücûmu'z-Zâhire, C. 13, s. 13.

123 A.g.e., C. 13, s. 13.

${ }^{124}$ A.g.e., , C. 13, s. 14.
} 
göndererek emekliye sevk edildiğini ve Halep'ten ayrılarak yeniden Kudüs'e dönmesini emrettiyse de Çekem, Nevrûz'un ayrılmasına izin vermedi. ${ }^{125}$ Çekem'in Halep'e hâkim olmasından sonra Mart-Nisan 1406'da Antakya hâkimi Türkmen emiri Bazoğlu Faris önderliğindeki Türkmenlerle Araplar (Urban) taşkınlık yapmaya başlamışlardı. Emir Nuayr b. Hayyâr liderliğindeki Araplar ise asayiş problemlerine neden oluyorlardı. Çekem, Kınnesrin'de Emir Nuayr'1 yenip Halep'te tutsak edince emaret-i urban (Arapların Yöneticisi) makamına Fazıloğullarından İbnü'l-Acl getirildi. ${ }^{126}$ Çekem, İbnü'l-Acl'i de tedip etmek istedi ve İbnü'lAcl, Çekem önünden kaçarak Selimiye'ye sığındı. Çekem'in Selimiye' de kendisini kuşatması üzerine özür dileyerek ona itaatini bildirmek zorunda kaldı. ${ }^{127}$

Sultan Ferec, Çekem'in bu tür faaliyetleriyle yeniden bir isyan teşebbüsünde bulunması üzerine onu Halep ve Trabulus niyâbeti görevinden azlederek Halep'e Emir Demirtaş elMuhammedî'yi, Trabulus'a ise Emir Allan el-Yahyavî atadı. ${ }^{128}$ Dımaşk nâibi Şeyh, eski dostu ve müttefiki olan Emir Çekem'in bu ikinci isyanını desteklemiyordu. Şeyh, Çekem yerine Halep'e atanan Emir Demirtaş, Trabulus'un yeni nâibi Allan el-Yahyavî ve Safed nâibi Emir Tülü ile birlikte Çekem ile mücadele için harekete geçti. Urban kuvvetlerinin de desteğini sağlayan Emir Şeyh, Çekem ile Hama-Humus arasında Asi Nehri civarındaki Rustan bölgesinde 11 Haziran 1406'da karşılaştı. ${ }^{129}$ Yapılan savaşı Çekem kazandı ve savaş sırasında Emir Tülü ve Allan el-Yahyavî öldürüldüler. ${ }^{130}$ Bozguna uğrayan Şeyh ve Demirtaş canlarını kurtarmak suretiyle Remle'ye kaçtılar. Rustan Zaferi'nden sonra 15 Haziran 1406'da Emir Nevrûz Dımaşk'a girerek halkı Çekem'i karşılamak üzere hazırladı. 15 Haziran'da artık klişe bir slogan haline gelen "Çekem, Çekem! Ve ma zelem (Çekem, Çekem! Artık yoktur zulüm)" tezahüratlarıyla Dımaşk'a giren Çekem, bir kez daha istiklâlini ilan etti. ${ }^{131}$ Şehirde herhangi bir asayiş sorunu yaşanmaması için askerlerine kesin emir veren Çekem, olası bir taşkınlığ 1 önlemek üzere geçici olarak içki yasağı koydu. Çekem, Dımaşk'ta saltanatını ikinci kez ilân ettikten sonra Dımaşk niyâbeti makamına Emir Nevrûz el-Hafızî’yi atadı ve ardından Halep'e döndü. ${ }^{132}$

\section{3. Üçüncü İsyanı ve İstiklâlini İlân Etmesi}

Dımaşk'ın Çekem'in hâkimiyetine girişinin ardından Sultan Ferec, Bilâd-1 Şam'daki devlet otoritesini sağlamak gayesiyle yeni bir Dımaşk seferi için hazırlıklara başladı. Hazırlıklar çerçevesinde el-Vâlid olaraf meşhur olup emekli olarak Kudüs'te bulunan Emir Tağrıberdi'yi Kahire'ye davet ederek onu Sağ Kol Kumandanlığı'na atadı. ${ }^{133}$ Rustan Savaşı'ndan mağlup olarak Remle'ye kaçan Emir Şeyh'i Dımaşk niyâbetine atadı ve Çekem'le mücadele için ona para ve silah gönderdi. ${ }^{134}$ Çekem, kısa süre içerisinde Safed, Kerek, Subeybe ve Gazze'yi ele geçirdi. Bu sırada Hama kadılarının “Allah'ım! Çekem'e yardım et” başlıklı mektubu posta güvercinleri vasıtasıyla Kahire'ye ulaşınca Ferec, seferi hızlandırmak zorunda kaldı. ${ }^{135} 20$ Temmuz 1406'da Emir Şeyh, Demirtaş, Hayır Bey, Altunboğa el-Osmanî, Yunus el-Hafizî,

\footnotetext{
125 A.g.e., C. 13, s. 15.

${ }^{126}$ Makrizî, a.g.e., C. 6, s. 161; İbn Tağriberdî, el-Menhelü's-Sâfî, C. 4, s. 320.

${ }^{127}$ Makrizî, a.g.e., C. 6, s. 159; İbn Hacer, a.g.e., C. 2, s. 326.

${ }^{128} \mathrm{Bu}$ şekilde Halep ve Trabulus niyâbetleri yeniden ayrı idari birimlere dönüştürülmüştür. (yazar)

${ }^{129}$ Makrizî, a.g.e., C. 6, s. 161; İbn Hacer, a.g.e., C. 2, s. 326; İbn Tağrıberdî, en-Nücûmu'z-Zâhire, C. 13, s. 16; Esra Çıplak, a.g.t., s. 35.

${ }^{130}$ Makrizî, a.g.e., C. 6, s. 161; İbn Hacer, a.g.e., C. 2, s. 327; İbn Tağrıberdî, en-Nücûmu'z-Zâhire, C. 13, s. 16; a. mlf., el-Menhelü's-Sâfi, C. 4, s. 320 vd; Sayrafí, a.g.e., C. 2, s. 220.

${ }_{131}$ Makrizî, a.g.e., C. 6, s. 162; İbn Tağriberdî, en-Nücûmu'z-Zâhire, C. 13, s. 16; Sayrafî, a.g.e., C. 2, s. 229.

132 İbn Tağrıberdî, en-Nücûmu'z-Zâhire, C. 13, s. 17.

${ }_{133}$ A.g.e., C. 13, s. 17.

${ }^{134}$ Makrizî, a.g.e., C. 6, s. 173; İbn Tağrıberdî, en-Nücûmu'z-Zâhire, C. 13, s. 17.

${ }^{135}$ İbn Tağrıberdî, en-Nücûmu'z-Zâhire, C. 13, s. 17.
} 
Sûdûn ez-Zarif, Tengizboğa el-Hutati ve Çekem'e karşı olan birçok Bilâd-1 Şam emiri Kahire'ye gelerek sultan tarafindan huzura kabul edildiler. ${ }^{136}$ Dımaşk'a yapılacak seferin ayrıntıları tespit edilerek Emir Şeyh Dımaşk; Emir Demirtaş ise Halep nâibi olarak atandılar. ${ }^{137}$

Emir Şeyh ve Emir Demirtaş önderliğindeki öncü birlikler 16 Ağustos 1406'da Dımaşk'a gitmek üzere Kahire'den ayrıldılar. ${ }^{138}$ Sultan Ferec, Emir Tımraz en-Nâsırı̂’yi yerine vekil bıraktıktan sonra üçüncü Dımaşk seferine çıktı ve 8 Eylül 1406' da Gazze'ye ulaştı. ${ }^{139} \mathrm{Bu}$ sırada Dulkadirli Nasreddin Mehmed Bey'i tedip etmek amacıyla Elbistan kuşatmasıyla meşgul olan Çekem, Ferec'in hareketi ve Emir Nevrûz'un tavsiyesiyle Elbistan kuşatmasını kaldırıp Halep'e döndü. ${ }^{140}$ Emir Nevrûz, Kahire ordusunun öncülerini karşılamak üzere Emir Sûdûn elMuhammedî ve Özbek ed-Devadâr mukaddemliğindeki bir birliği Remle'ye gönderdi. ${ }^{141}$ Nevrûz'un gönderdiği ordu, Kahire birliği karşısında tutunamayarak dağıldı. Emir Nevrûz, Kahire ordusuna direnemeyeceğini anlayarak Çekem'e sığınmak üzere Halep'e kaçtı. Nevrûz'un Halep'e kaçmasından sonra Safed, Baalbek, Humus ve nihayetinde Dımaşk yeniden devlet kontrolüne alındı. Emir Şeyh'in Dımaşk'a girmesinden kısa süre sonra 21 Eylül 1406'da Sultan Ferec, Dımaşk'a ulaştı. ${ }^{142}$ Dımaşk'ta yaklaşık on gün kalan sultan, 1 Ekim'de Halep seferine çıktı. ${ }^{143}$ Çekem, sultanın Halep'e yönelmesi üzerine Nevrûz ve Timurboğa el-Meştûb ile birlikte kuzey tarafındaki Fırat boylarına kaçtı. Halep'e giren Ferec, Çekem'i yakalamak üzere Fırat boylarına bir tecrid birliği yolladıktan sonra Halep niyâbetine Emir Çerkes elKasımî el-Musarî'yi, Trabulus'a ise Emir Sûdûn Bekçe'yi atadı ve yaklaşık bir ay kaldığı Halep'ten 17 Kasım 1406'da ayrılarak Dımaşk'a döndü. ${ }^{144}$

Sultan Ferec'in Halep'ten ayrılmasından kısa süre sonra Fırat boylarında savunmaya çekilmiş olan Emir Nevrûz yeniden Halep'e geldi. Halep'in yeni nâibi Emir Çerkes, Nevrûz'dan kaçarak o sırada Dımaşk'a hareket halinde olan sultana yetişti. Nevrûz, Halep'e yeniden hâkim olduktan sonra Hama ve Humus'u ele geçirdi. ${ }^{145} 27$ Kasım 1406'daki bu hadiseden kısa süre sonra Çekem, Halep'e döndü. ${ }^{146}$ Halep ve Hama'nın Çekem kuvvetleri tarafından yeniden ele geçirilmesi üzerine sultan, iki ay boyunca Dımaşk'ta kalacağını ilân ederek yeni bir Halep seferi için hazırlık yaptı. Memlûklu emirleri, askerlerin ve binek hayvanlarının yorgun olduğunu ileri sürerek yeni bir Halep seferine çıkmak istemiyorlardı. Sultan, Çekem'i kesin olarak ortadan kaldırmak istediğinden emirlerden gelen talebi dikkate almayarak Halep'e gitmek üzere şehir dışına kadar hareket ettiyse de geri dönmek zorunda kaldi. $^{147}$

\footnotetext{
${ }^{136}$ Makrizî, a.g.e., C. 6, s. 173; İbn Hacer, a.g.e., C. 2, s. 351; İbn Tağrıberdî, en-Nücûmu'z-Zâhire, C. 13, s. 17 vd; Sayrafî, a.g.e., C. 2, s. 224.

${ }^{137}$ Makrizî, a.g.e., C. 6, s. 173; İbn Hacer, a.g.e., C. 2, s. 351; İbn Tağrıberdî, en-Nücûmu'z-Zâhire, C. 13, s. 18; Sayrafî, a.g.e., C. 2, s. 224.

${ }^{138}$ Makrizî, a.g.e., C. 6, s. 174; İbn Hacer, a.g.e., C. 2, s. 351; İbn Tağrıberdî, en-Nücûmu'z-Zâhire, C. 13, s. 18; Sayrafî, a.g.e., C. 2, s. 225.

${ }^{139}$ Makrizî, a.g.e., C. 6, s. 174; İbn Hacer, a.g.e., C. 2, s. 352; İbn Tağrıberdî, en-Nücûmu'z-Zâhire, C. 13, s. 19; Sayrafî, a.g.e., C. 2, s. 225, 226.

${ }_{140}$ Refet Yinanç, a.g.e., s. 37.

${ }^{141}$ Makrizî, a.g.e., C. 6, s. 174; Esra Çıplak, a.g.t., s. 36

142 Makrizî, a.g.e., C. 6, s. 175; İbn Hacer, a.g.e., C. 2, s. 352; İbn Tağrıberdî, en-Nücûmu'z-Zâhire, C. 13, s. 19.

${ }^{143}$ Makrizî, a.g.e., C. 6, s. 175; İbn Hacer, a.g.e., C. 2, s. 353; İbn Tağrıberdî, en-Nücûmu'z-Zâhire, C. 13, s. 19; Sayrafî, a.g.e., C. 2, s. 226.

${ }^{144}$ Makrizî, a.g.e., C. 6, s. 176; İbn Hacer, a.g.e., C. 2, s. 353 vd; İbn Tağrıberdî, en-Nücûmu'z-Zâhire, C. 13, s. 19; Sayrafî, a.g.e., C. 2, s. 227; Esra Çıplak, a.g.t., s. 36 vd.

${ }_{145}$ Makrizî, a.g.e., C. 6, s. 176; İbn Tağriberdî, en-Nücûmu'z-Zâhire, C. 13, s. 20.

${ }^{146}$ Makrizî, a.g.e., C. 6, s. 176; İbn Hacer, a.g.e., C. 2, s. 354; İbn Tağrıberdî, en-Nücûmu'z-Zâhire, C. 13, s. 19; Sayrafî, a.g.e., C. 2, s. 227

${ }^{147}$ Makrizî, a.g.e., C. 6, s. 176; İbn Tağrıberdî, en-Nücûmu'z-Zâhire, C. 13, s. 20.
} 
Sultan Ferec, Çekem'in Bilâd-1 Şam emirleri ve halkı üzerindeki nüfuzunu bildiğinden onu bir an önce ortadan kaldırmak istiyor; fakat yıpranan ordusu buna mani oluyordu. Sultan, Dımaşk nâibi Emir Şeyh, Demirtaş el-Muhammedî ve Altunboğa el-Osmanî’nin yer aldığı bir orduyla Kahire'ye gitmek üzere Dımaşk'tan çıktı. Kudüs'e ulaştığında Sûdûn el-Hamzavî de onlara katıldı. Emir Şeyh ve Sûdûn el-Hamzavî, Kudüs'ten Safed'i ele geçirmek üzere buraya hareket ederken sultan da beraberinde Altunboğa el-Osmanî olduğu halde Kahire'ye doğru yola çıktı ve perişan bir halde Kahire'ye ulaşt1. ${ }^{148}$ Emir Şeyh ve Sûdûn Hamzavî, Çekem'in hâkimiyetindeki Safed'i ele geçirmeyi başardılar. Safed'in ele geçirilmesinden sonra Sûdûn elHamzavî, Çekem ve Şeyh arasında bir barış yapılması için teklifte bulundu; fakat Çekem bunu kabul etmedi. Sûdûn, Safed'den ayrıldıktan sonra Emir Çekem saflarına katıldı. Sûdûn elHamzavî’nin Çekem safına katılmasının ardından Emir Nevrûz Dımaşk'a girdi. ${ }^{149} \mathrm{Bu}$ sırada Kahire emirlerinden olan İnal Bay b. Korkmaz ve Yeşbek b. Özdemir de Çekem safina katıldılar. ${ }^{150}$ Oldukça güçlenen Çekem kuvvetleri Gazze, Remle ve Kerek'i ele geçirmeyi başardılar. ${ }^{151}$ Çekem bu başarılarının ardından 20 Şubat 1407 tarihinde karargâhı olan Halep’te "Sultan Melikü'l-Âdil Ebi'l-Fütûh Abdillah Çekem" lakabı ile kendisini üçüncü kez sultan ilân etti. ${ }^{152} \mathrm{Bu}$ şekilde Safed hariç olmak üzere Gazze'den Elbistan'a kadar olan geniş bölgede hâkimiyetini tesis etmişti. ${ }^{153}$ Önceki iki isyanından farklı olarak bu kez istiklâlini de ilân eden Çekem, başkent Kahire'deki emir, asker ve bürokratlarla çiftçi ve köylülere mektuplar yollayarak saltanatını ilân ettiğini ve artık Ferec'e biat etmemelerini bildirdi. Ayrıca Kahire'ye ödedikleri vergileri artık ödememeleri hususunda urban, çiftçi ve köylülere uyarılarda bulundu. ${ }^{154}$ Ardından da 28 Mart 1407 'de ilk atamalarını yaptı: Devadârlık makamına Emir Sûdûn el-Hamzavî, emir-i ahur makamına Emir İnal Bay b. Korkmaz, reis-i nevbet makamına Emir Yeşbek b. Özdemir atandılar. Emir Nevrûz ise Dımaşk niyâbetine atandı. ${ }^{155}$

Sultan Ferec, Kahire'ye döndükten sonra Emir Timraz en-Nâsırî ve Emir Akbay önderliğinde yeni bir tecrid birliğini Çekem üzerine yolladıysa da Çekem ordusunun Gazze, Katya ve Kerek'i ele geçirmesi üzerine birlik, uzun süre beklediği Bilbis'ten Kahire'ye dönmek zorunda kalmıştı. ${ }^{156}$

\section{5- Ölümü}

Çekem, Elbistan'dan Gazze'ye kadar olan sahada istiklâlini ilân ettikten sonra yönünü Mardin ve Diyarbakır bölgesine çevirdi. 1405 ve 1406'daki isyanlarında Kahire halkı Çekem'e ilgi göstermemişti. Safed haricindeki tüm Bilâd-1 Şam şehirlerinde Çekem'e biat edilmiş olması nedeniyle Çekem, Kahire'de tahta oturmak yerine Halep ve mülhakatında bağımsız bir lider olarak kalmayı tercih etti. Mardin ve Diyarbakır bölgesinin tarımsal üretim ve ticari potansiyel bakımından oldukça zengin oluşu, Mardin hâkimi Melikü'z-zahir Necmüddin İsa’nın, Kara

\footnotetext{
${ }^{148}$ Makrizî, a.g.e., C. 6, s. 178; İbn Tağrıberdî, en-Nücûmu'z-Zâhire, C. 13, s. 20.

${ }^{149}$ Makrizî, a.g.e., C. 6, s. 179; İbn Tağrıberdî, en-Nücûmu'z-Zâhire, C. 13, s. 21.

${ }^{150}$ Makrizî, a.g.e., C. 6, s. 180; İbn Tağrıberdî, en-Nücûmu'z-Zâhire, C. 13, s. 21.

${ }^{151}$ Makrizî ve İbn Tağrıberdî, Çekem'in istiklâlini 20 Şubat 1407'de ilan ettiğini kaydederken (Makrizî, a.g.e., C. 6, s. 180; İbn Tağrıberdî, en-Nücûmu'z-Zâhire, C. 13, s. 22) İbn Hacer ve Sayrafî, 21 Kasım 1406 tarihini vermektedirler (İbn Hacer, a.g.e., C. 2, s. 356; Sayrafî, a.g.e., C. 2, s. 229). Yukarıda da işaret edildiği gibi Çekem, 27 Kasım 1406'da Fırat boylarından Halep'e dönmüş ve ancak Sultan Ferec'in Dımaşk'tan ayrılmasında sonra saltanatını ilan edebilmiștir. Dolayısıyla Makrizî ve İbn Tağrıberdî'deki kayıt doğru olmalıdır.

${ }^{152}$ Makrizî, a.g.e., C. 6, s. 181; İbn Tağrıberdî, en-Nücûmu'z-Zâhire, C. 13, s. 22; a. mlf., el-Menhelü's-Sâfî́, C. 4, s. 321; Esra Çıplak, a.g.t., s. 37.

${ }^{153}$ Makrizî, a.g.e., C. 6, s. 181; İbn Hacer, a.g.e., C. 2, s. 356; İbn Tağrıberdî, en-Nücûmu'z-Zâhire, C. 13, s. 22; Ebu Bekr-i Tihranî, Kitab-ı Diyarbekriyye, Çev: Mürsel Öztürk, Ankara 2001, s. 49; Sayrafî, a.g.e., C. 2, s. 230; İbn Îyâs, a.g.e., s. 306; Hasan-1 Rumlu, Ahsenü't-Tevârîh, Çev: Mürsel Öztürk, TTK., Ankara 2006, s. 48.

${ }^{154}$ Makrizî, a.g.e., C. 6, s. 181; İbn Tağrıberdî, en-Nücûmu'z-Zâhire, C. 13, s. 22.

${ }^{155}$ Makrizî, a.g.e., C. 6, s. 181; İbn Tağriberdî, en-Nücûmu'z-Zâhire, C. 13, s. 22.

${ }^{156}$ Makrizî, a.g.e., C. 6, s. 180-181; İbn Tağrıberdî, en-Nücûmu'z-Zâhire, C. 13, s. 21-22.
}

\section{History Studies}


Yülük Osman'a (?- 1435) karşı Emir Çekem'den yardım istemesi ${ }^{157}$ ve daha önce Çekem'e bağlı olan İnallu ve Bayat Türkmenlerinden bir topluluğun Çekem'den ayrılarak Kara Yülük Osman Bey'e iltica etmeleri ve Çekem'in Osman Bey'den adı geçen Türkmen topluluklarının iadesini istemesine rağmen Kara Yülük bu teklifi reddetmesi nedenleriyle Çekem, Diyarbakır seferine çıktı. ${ }^{158}$

Çekem, Nisan-Mayıs 1407'de yanında Emir Timurboğa el-Meştûb, Nasıreddin Muhammed b. Şehrî, Gümüşboğa el-İsevî ve diğer emirler olduğu halde Halep’ten çıkarak Bire’ye (Birecik) ulaştı ve Bire nâibi Emir Güzel'i öldürdükten sonra şehre hâkim oldu. ${ }^{159}$ Kara Yülük Osman Bey, Çekem'in hareketini yakından takip ederek tedbirli davranıyordu. Çekem'in Diyarbakır tarafına olası bir hareketini önlemek amacıyla elçisini çok sayıda deve, koyun ve binek hayvanı ile birlikte Bire'de bulunan Çekem'e yollayarak ona itaatini bildirdiyse de Çekem bunu kabul etmedi. ${ }^{160}$ Ardından Mardin'e geçen Çekem, Kızıltepe yakınlarındaki Harzem bölgesinde konuşlandı. ${ }^{161}$ Şehrin Artuklu Beyi Necmeddin İsa'yı ve hâcibi Feyyâz'ı itaati altına aldıktan sonra Hâcib Feyyâz'1 Kara Yülük Osman'a göndererek ondan Diyarbakır'ı istedi. Kara Yülük'ün teklifi reddetmesi üzerine Diyarbakır'a yöneldi. ${ }^{162}$ Çekem, yaklaşık 7.000 kişilik kuvvetiyle Diyarbakır önlerine gelip şehrin güneyindeki sayfiye alan olan Ali Pınarı'na yerleşti. ${ }^{163}$ Burada Bayındır Türkmenleriyle girdiği çatışmaları kazanan Çekem, bu çatışmaların birinde Kara Yülük Osman Bey'in oğlu İbrahim Beyi öldürdü. ${ }^{164}$ İbrahim Beyin ölümü iki kuvvet arasındaki savaşı kaçınılmaz kıldı.

Kara Yülük Osman Bey, muhkem Diyarbakır surlarına güveniyor ve savunma stratejisi takip ediyordu. Ayrıca, Çekem'in her adımını dikkatle takip ediyor ve onun surlar etrafındaki sulak ve sazlık alan olan Hevsel Bahçeleri'ne girmesini bekliyordu. Eskiçağlardan beri Diyarbakır mülhakatındaki en verimli arazilerden olan Hevsel Bahçeleri, geniş sazlıklara sahipti ve bu sazlıklara atla girilmesi oldukça tehlikeliydi. Çekem, 4 Haziran 1407 'de ${ }^{165}$ atıyla birlikte bu sazlıklara girince onu takip eden Türkmenler, taşlarla Çekem ve mahiyetine saldırdılar. Yüzünden ve çenesinden yaralanan Çekem, ok yağmuruna tutuldu ve atından düşerek öldü. ${ }^{166}$ Çekem'le birlikte Mardin hâkimi Emir Mecdüdin İsa, Halep Hâcibü’l-hüccâbı Nasıreddin Muhammed b. Şehrî, Antep nâibi Emir Kumuk ve Emir Sarı Seyyidî de öldürülmüştü. ${ }^{167}$ Kara Yülük Osman Bey, Çekem ve İbn Şehrî’nin başlarını gövdelerinden

\footnotetext{
${ }^{157}$ Hasan-1 Rumlu, a.g.e., s. 48 vd; İlhan Erdem, "Akkoyunlu Devleti’nin Kurucusu Kara Yülük Osman Bey ve Faaliyetleri (?-1435)", Ankara Üniversitesi Dil ve Tarih-Coğrafya Fakültesi Dergisi, C.34, 1-2, Ankara 1990, s. 101; Elif Kocakaplan, Kara Yülük Osman Bey Dönemi (1403-1435) Akkoyunlu Tarihi, Basılmamış Yüksek Lisans Tezi, İnönü Üniversitesi Sosyal Bilimler Enstitüsü, Malatya 2019, s. 42.

${ }^{158}$ Ebu Bekr-i Tihranî, a.g.e., s. 50; Hasan-1 Rumlu, a.g.e., s. 49; İlhan Erdem, a.g.m., s. 101; Elif Kocakaplan, a.g.t., s. 42.

${ }^{159}$ Makrizî, a.g.e., C. 6, s. 184; İbn Hacer, a.g.e., C. 2, s. 356; İbn Tağrıberdî, en-Nücûmu'z-Zâhire, C. 13, s. 24; a. mlf., el-Menhelü's-Sâfí, C. 4, s. 322.

${ }_{160}$ Makrizî, a.g.e., C. 6, s. 184; İbn Tağrıberdî, en-Nücûmu'z-Zâhire, C. 13, s. 24.

${ }^{161}$ Ebu Bekr-i Tihranî, a.g.e., s. 50.

${ }_{162}^{16}$ Makrizî, a.g.e., C. 6, s. 184; İbn Hacer, a.g.e., C. 2, s. 357; İbn Tağrıberdî, en-Nücûmu'z-Zâhire, C. 13, s. 24.

${ }^{163}$ Ebu Bekr-i Tihranî, a.g.e., s. 51.

${ }^{164}$ Makrizî, a.g.e., C. 6, s. 184; İbn Tağrıberdî, en-Nücûmu'z-Zâhire, C. 13, s. 24; a. mlf., el-Menhelü's-Sâfí, C. 4, s. 322; Ebu Bekr-i Tihranî, a.g.e., s. 52; Hasan-1 Rumlu, a.g.e., s. 51 vd; Elif Kocakaplan, a.g.t., s. 43.

${ }^{165}$ Makrizî, ve Sayrafî, Çekem'in ölüm tarihini 4 Haziran 1407 olarak verirken İbn Tağriberdî, en-Nücûmu'z-Zâhire adlı eserinde 25 Mayıs 1407; el-Menhelü's-Sâfi adlı eserinde ise 3 Mayıs 1407 olarak kaydetmektedir. Bkz. Makrizî, a.g.e, C. 6, s. 185; Sayrafî, a.g.e., C. 2, s. 231; İbn Tağrıberdî, en-Nücûmu'z-Zâhire, C. 13, s. 25; a. mlf., elMenhelü's-Sâfí, C. 4, s. 323.

${ }^{166}$ Makrizî, a.g.e., C. 6, s. 185; İbn Hacer, a.g.e., C. 2, s. 357; İbn Tağrıberdî, en-Nücûmu'z-Zâhire, C. 13, s. 25; a. mlf., el-Menhelü's-Sâfí, C. 4, s. 322.

${ }^{167}$ Makrizî, a.g.e., C. 6, s. 185; İbn Hacer, a.g.e., C. 2, s. 357; İbn Tağrıberdî, en-Nücûmu'z-Zâhire, C. 13, s. 25; a. mlf., el-Menhelü's-Sâfí, C. 4, s. 323; Sayrafî, a.g.e., C. 2, s. 231.
}

\section{History Studies}


ayırmak suretiyle oğlu İbrahim'in intikamını almış oldu. Çekem'in ölüm haberi üzerine Kahire'de üç gün kutlama yapıldı. Daha sonra ise Çekem ve İbn Şehrî'nin kesik başları Kahire'ye yollandı. 17 Haziran 1407'de Emir Nuayr, Çekem ve İbn Şehrî’nin başlarını Kahire'ye getirdi. Sultan Ferec, her iki başı iki sırı̆ga geçirerek Kahire sokaklarında gezdirtti. Ardından Çekem'in kesik başı Bâb-1 Züveyle'ye, İbn Şehrî'ninki ise Bâb-1 Zeynîye'ye asılarak teşhir edildiler. ${ }^{168}$

\section{6- Çekem'in Ölümünden Sonra Bilâd-ı Şam'daki Gelişmeler}

Sultan Ferec, Bilâd-1 Şam'ın Çekem'in hâkimiyetine girmesi üzerine Mısır'daki taun salgınına ve emirlerin itirazına rağmen Çekem'i ortadan kaldırmak amacıyla bir tecrid birliği hazırlamış bu birlik Kahire'den harekete edecek iken Çekem'in ölüm haberi üzerine sefer iptal edilmişti. ${ }^{169}$ Çekem'in öldürülmesi üzerine Bilâd-1 Şam'da Sultan Ferec'e bağlı tek emir olan Safed hâkimi Emir Şeyh, o sırada Gazze'de bulunan Çekem taraftârı Emir İnal Bay, Sûdûn elHamzavî, Yeşbek b. Özdemir, Yunus el-Hutatî ve Sûdûn Kurnas'1 yakalamak üzere Gazze'ye gitti. Burada yapılan savaşta İnal Bay, Yunus el-Hutatî ve Sûdûn Kurnas öldürüldüler. Sûdûn el-Hamzavî’nin gözlerine mil çekildi. Yeşbek b. Özdemir ise Dımaşk'a kaçmayı başardı. ${ }^{170} \mathrm{Bu}$ arada Çekem ile birlikte Diyarbakır kuşatmasında yer alan Emir Timurboğa el- Meştûb ve Emir Gümüşboğa el-İsevî, Çekem'in öldürülmesinden sonra Halep'e gelerek şehre hâkim oldular. ${ }^{171}$ Dımaşk niyâbeti makamını Çekem adına temsil eden Emir Nevrûz ise Çekem'in Diyarbakır kuşatması ile meşgul olduğu dönemde Dımaşk'ta Çekem adına okunan hutbeyi kaldırarak Sultan Ferec'e itaat etmişti. ${ }^{172}$ Sultan Ferec, Bilâd-1 Şam'da Memlûklu hâkimiyetini yeniden tesis etmek gayesiyle 26 Haziran 1407 'de dördüncü Dımaşk seferine çıktı. ${ }^{173}$

\section{Sonuç}

Dönemin kaynaklarında şiir ve nazımdan hoşlanan, fikhî konulara vâkıf ve âdil bir devlet adamı olarak tarif edilen Emir Çekem, Bahrî Memlûkleri döneminin ilk sultanı Berkûk'un yetiştirmesi olduğundan Sultan Ferec döneminde oldukça etkili olmuştur. Devlet işlerini kontrolü altına almaya çalışarak Emir Nevrûz ile birlikte hareket etmiş ve Sûdûn elHamzavî’ye karşı giriştiği güç çatışmasını kaybederek İskenderîye Hapishanesi'ne yollanmıştır. Timur'un Bilâd-1 Şam'ı (Suriye) ele geçirmesinin yarattığı siyasî karışıklıklar Çekem'in yeniden güçlenmesine imkân sağlamıştır. Yaklaşık iki yıllık hapis hayatından sonra kendisine duyulan lüzum üzerine serbest kalınca Halep'i ele geçirerek kısa süre içerisinde saltanatını ilân etmiştir. Saltanatını ilân ederken Dokmak el-Muhammedî, Allan el-Yahyâvî ve Emir Tülü gibi hoşdaşlarını öldürmekten çekinmemiştir. Timur'un bölge halkı üzerinde bıraktığ1 psikolojik tahribat, taze ve muktedir bir güce olan gereksinimi doğurmuş ve Çekem, bu durumu lehine çevirerek halkın desteğini kazanmıştır. Nitekim halkın onu "Çekem, Çekem! Artık yoktur zulüm” tezahüratlarıyla karşılaması bunu kanıtlamaktadır.

\footnotetext{
${ }^{168}$ Makrizî, a.g.e., C. 6, s. 189 vd; İbn Hacer, a.g.e., C. 2, s. 358; İbn Tağrıberdî, en-Nücûmu'z-Zâhire, C. 13, s. 26; Sayrafî, a.g.e., C. 2, s. 238; Merhum Refet Yinanç, Dulkadir Beyliği adlı eserinde, kaynak belirtmeden Kara Yülük Osman'ın zafer işareti olarak Çekem'in kesik elini Sultan Ferec'e gönderdiğini ve sultanın bu kesik eli Dulkadirli Nasreddin Mehmet Bey'e göndererek onu rahatlattı̆̆ı söylemektedir (Bkz. Refet Yinanç, a.g.e., s. 37). Esra Çıplak da Refet Yinanç'daki bu kaydı olduğu gibi aktarmaktadır (Bkz. Esra Çıplak, a.g.t., s. 38). Dulkadirlilere ait araştırmalarda oldukça mühim bir yere sahip olan ve sıklıkla istifade ettiğimiz Dulkadir Beyliği adlı eserde Emir Çekem'e dair geçen bu bilgiye kaynak gösterilmediği için ihtiyatla yaklaşıyoruz (yazar).

${ }^{169}$ Makrizî, a.g.e., C. 6, s. 184; İ̉n Tağriberdî, en-Nücûmu'z-Zâhire, C. 13, s. 22 vd.

${ }^{170}$ Makrizî, a.g.e., C. 6, s. 185; İbn Tağrıberdî, en-Nücûmu'z-Zâhire, C. 13, s. 25 vd; Sayrafî̀, a.g.e., C. 2, s. 231 vd.

${ }^{171}$ İbn Tağrıberdî, en-Nücûmu'z-Zâhire, C. 13, s. 26.

172 Makrizî, a.g.e., C. 6, s. 185; İbn Tağrıberdî, en-Nücûmu'z-Zâhire, C. 13, s. 26.

${ }^{173}$ İbn Tağrıberdî, en-Nücûmu'z-Zâhire, C. 13, s. 26; Sayrafî, a.g.e., C. 2, s. 239.
} 
Çekem, Emir Şeyh başta olmak üzere bölgedeki diğer Memlûklu emirleriyle ittifak ederek Kahire'yi ele geçirmeye çalışmış; fakat başarısız olarak geri çekilmek zorunda kalmıştır. Kahire kamuoyunun desteğini sağlayamadığ 1 için Sultan Ferec'e biat etmek zorunda kalmış; onun tahttan feragat etmesiyle yeniden isyan etmiştir. Üçüncü isyanında Kahire'yi ele geçirmek yerine ciddi destek bulduğu Halep ve çevresinde güçlenmeyi hedeflemiştir. Kısa süreliğine de olsa bu hedefine ulaşan Çekem, Gazze'den Elbistan'a kadar olan geniş sahada hâkimiyetini kurmayı başarmıştır. Ekonomik ve siyasi gerekçelerle kuzeye doğru bir genişleme siyaseti güden Çekem, Diyarbakır ve mülhakatında hâkim Akkoyunlu Beyi Kara Yülük ile giriştiği mücadeleyi kaybederek öldürülmüştür. Onun öldürülmesi Memlûklu-Akkoyunlu ilişkilerine olumlu yansımıştır.

\section{Kaynakça}

ÇIPLAK, Esra, el-Melik en-Nâsır Ferec b. Berkuk Devri Memlûk Sultanlı̆̆ (791-815/13891412), Basılmamış Yüksek Lisans Tezi, Gazi Üniversitesi Sosyal Bilimler Enstitüsü, Ankara 2005.

ÇUBUKÇU, Asri, "Ferec”, DİA, C. 12, İstanbul 1995, s. 370-371.

EBU BEKR-İ TİHRANî, Kitab-ı Diyarbekriyye, Çev: Mürsel Öztürk, Ankara 2001.

ERDEM, İlhan, “Akkoyunlu Devleti’nin Kurucusu Kara Yülük Osman Bey ve Faaliyetleri (?1435)", Ankara Üniversitesi Dil ve Tarih-Coğrafya Fakültesi Dergisi, C.34, 1-2, Ankara 1990, s. 99-108.

HASAN-I RUMLU, Ahsenü't-Tevârîh, Çev: Mürsel Öztürk, TTK., Ankara 2006.

İBN HACER, İnbâu'l-Ğumr Ebnâi'l-Umr, Tahkik: Hasan Habeşî, C. 2, Kahire 2011.

İBN ÎYÂS, Bedâiü'z-Zuhûr fî Vekâiü'd-Duhûr, yy., 1960.

İBN TAĞRIBERDÎ, el-Menhelü's-Sâfì ve'l-Müstevfî bâde'l-Vâfî, Tahkik: Muhammed Muhammed Emin, C. 4, Kahire 1986.

İBN TAĞRIBERDÎ, en-Nücûmu'z-Zâhire fî Mülûk-ı Mısr ve'l-Kâhire, Tahkik: Muhammed Hüseyin Şemseddin, C. 12-13, Beyrut 1992.

KOCAKAPLAN, Elif, Kara Yülük Osman Bey Dönemi (1403-1435) Akkoyunlu Tarihi, Basılmamış Yüksek Lisans Tezi, İnönü Üniversitesi Sosyal Bilimler Enstitüsü, Malatyal 2019.

MAKRİZî, es-Sülûk li-Marifet-i Düvelü'l-Mülûk, Tahkik: Muhammed Abdülkadir Âtâ, C. 5-6, Beyrut 1997.

SAYRAFÎ, Nüzhetü'n-Nüfûs ve'l-Abidân fî Tevârihi'z-Zamân, Tahkik: Hasan Habeşî, C.2, yy. 1971.

SEHÂVÎ, ed-Dâvü'l-Lâmî li-Ehli'l-Karni't-Tâsî, C. 3, Beyrut 1992.

YİĞİT, İsmail, Memlûkler 648-923/1250-1517, Kayıhan Yay., İstanbul 2015.

YİNANÇ, Rıfat, Dulkadir Beyliği, TTK., Ankara 1989.

ZENGIN, Murat, "Melikü'l-Muzaffer Zeyneddin Haccî Döneminde Memlükler”, Tarihin Peşinde- Uluslararası Tarih ve Sosyal Araştırmalar Dergisi, C. X/, 20, Ekim 2018, s. 357-373. 
ZENGİN, Murat, “Melikü'n-Mansûr Ebî Bekr b. Muhammed Dönemi Memlûk Türk Devleti Tarihi (Elli Dokuz Günlük Saltanat)”, History Studies, C. X, 3, April 2108, s. 257-270.

ZENGIN, Murat, "Sultan Selâhaddin Sâlih Döneminde Memlükler”, Tarih Okulu Dergisi, C. XII, 39, Nisan 2019, s. 313-332.

ZENGİN, Murat, İhanlılar-Eratnalılar-Memlûkler Dönemi Malatya (1295-1401), Malatya Kitaplığı, İstanbul 2017. 